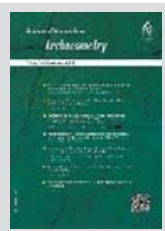

Original Paper

\title{
The Natural Mummies of Zanjan Salt Mine and Preventive Conservation Approach for their Preservation
}

\author{
Manijeh Hadian Dehkordi* \\ Assistant professor of Research Center for Conservation of Cultural Relics, Tehran, IRAN
}

Received: 22/05/2021

Accepted: 21/08/2021

\begin{abstract}
:
Some archeological studies in order to identify and introduce the natural mummies so-called Salt men discovered in the Chehrabad salt mine in Zanjan in western Iran and how to preserve them before 2010 are the contents of this article. These artifacts were first discovered accidentally in 1993 and 2004, and then by conducting archeological excavations. Methods used in these studies include: carbon 14 dating, radiographic imaging and CT scan, DNA molecular studies, $13 \mathrm{C}$ and $15 \mathrm{~N}$ isotope analysis, trace element analysis by ICP method. The results of studies showed that these bodies with different ages belong to the Achaemenid and Sassanid periods, which were buried there as a result of mine collapse in the above historical periods. In addition, the study of the salt men decay process showed that relative humidity and its fluctuations are one of the most important environmental variables affecting this process and the threat to these properties. Periodic inspections and monitoring and biological tests (fungal and bacterial tests) showed that the method of preventive conservation has been the best and most effective method to preserve them.
\end{abstract}

Keywords: Salt men, Chehrabad Salt mine, Natural mummy, Archeometry, Preventive conservation .

\section{Introduction}

Some three decades have passed since the discovery of the salt-man, the first natural-historical mummy, at Zanjan Chehrabad Salt Mine in 1993. This mine is located in the province of Zanjan, a city in the west of Iran and at the altitude of $1350 \mathrm{~m}$ from the high seas with the coordinates of E47 5125 and N36 54 52. From 1993 until today, nearly three decades later, the remains of at least eight bodies, all of them called salt men, have been discovered there. The first two Salt men were discovered accidentally in 1993 and 2004 and then during archaeological excavations in 2004 and 2005 (salt men No. 3, 4 and 5) in this mine. Also, other human remains (salt men No. 6, 7 and 8) were discovered and identified which during the archeological excavation undertaken from 2010 onwards which went beyond the temporal scope of the present study [1-5]. Physically-speaking, the salt men no. 1 and no. 4 are among the most unique mummies discovered .

*Corresponding Author: m_hadian@yahoo.com

Copyright $@ 2021$, the Authors / This open-access article is published under the terms of the Creative Commons Attribution-NonCommercial 4.0 International License which permits Share (copy and redistribute the material in any medium or format) and Adapt (remix, transform, and build upon the material) under the Attribution-NonCommercial .terms 


\section{Materials and Methods}

As some questions had been raised about theses mummified corpses, the present interdisciplinary study was conducted to get more information about the salt-men and disclose the secrets hidden in their presence at the salt mine on the one hand and to understand the procedure for their conservation and preservation. The date of these properties was determined by applying carbon-14 dating through the AMS technique. The radiographic imaging and CT-Scan were applied for the pathology as well as determining the age and gender of the salt men no. 1 and no. 4. DNA molecular studies on the torso of the salt man no. 1 and his shin contributed to identification of a corpse. Additionally, an investigation was undertaken to analyze the $13 \mathrm{C}$ and $15 \mathrm{~N}$ isotopes existing in the soft tissues and the hair of the salt-men to specify their diets. The analysis on the trace elements existing in the hair of the salt man no. 1 was conducted via ICP. Furthermore environmental monitoring, field survey and microbiological studies on the mummies, were the considerations in line with their conservation .

\section{Results and Discussion}

The results of carbon-14 dating revealed that these corpses belong to historical periods of Achaemenides and Sassanid empires (Table 1 and 2) $[13,16]$. DNA molecular studies on the torso of the salt man no. 1 and his shin showed that they are contributed a corpse. Physical positions of corpses at the burial time and types of damages (Fig. 2 and Fig.3) sustained by them revealed by radiographic imaging and CT-Scan indicated that the cause of their deaths had been the collapse of the mines in the aforesaid historic periods that resulted in heavy pressures on them due to falling slat stones and numerous fractures inflicted on their skeletons (Fig. 4 and Fig. 6). The CT-Scan and analysis on the trace elements existing in the hair of the slat-man number 1 (Table 3) revealed that he was a middle-age man (around 40 years old) and the salt man no. 4 to be 15 or 16 years old boy (Fig. 5) [14]. Analyzing the $13 \mathrm{C}$ and $15 \mathrm{~N}$ isotopes existing in the samples taken from these properties and comparing them with the control cases suggested that their diets were something close to a marine diet (Table 4 and Fig. 8) [16, 18]. Given the geographical location of the mine and its distance from the seas (Fig. 1), one could conclude that these individuals were not form the local community; however, proving this point required further information and experiments. Investigating the decay process on the salt men's bodies [19-21] that covered not only their bones and soft tissues but also various objects such as different types of textiles (cloth, leather and skin of animals) and metals (iron and silver), indicated that the relative humidity was one of the most important environmental variables affecting this process and it was considered to be the main threat for these properties. Using the silica gel not only contributes to controlling the moderate moisture inside the showcases of these properties [23], but also is influential in absorption of gas pollutants emanating from the construction materials. Periodic monitoring and biological tests (fungi and bacteria) on the salt man no. 1 revealed that various parts of the torso and shins inside the boots were free on fungi. However, some aerobic bacteria were found in the boots (Bacillus Coagulans) and torsos (Acinetobacter spp, Staphylococcus epidermidis, and Staphylococcus aureus). Therefore, results of studies indicated that the preventive conservation used for these items over a period of 8 years had preserved them safe at Iranian National Museum in Tehran (Fig. 9). The same preventive conservation method was utilized for other salt men in the city of Zanjan (Fig. 10 and Fig. 11). The showcase for the salt man no. 4, the most intact mummy, together with its accompanying items was designed in a way to control the micro climate inside the showcase and concurrently to remove pests such as insects and micro-organism inside via creating low-oxygen environment through injecting nitrogen or CO2 inside the showcase, if required (Fig. 13) [26-30].

\section{Conclusion}

Considering the type of attire, ornaments, and objects found at the site such as gold earrings, long leather boots, short pants with color patterns belong to salt man no.1 as well as the silver earrings, the skin-shaped cape, short leather boots and the clothes of salt man no.4, one could draw the conclusion that they were not necessarily miners and they belonged to various social classes. Generally, it could be concluded that the salt men with different ages were victims who had gone to the mine to extract salt and had encountered the collapse of the mine at various time periods 
(Achaemenides and Sassanid empires) .

Due to the diversity of materials (organic and inorganic) in this collection and on the other hand the historical and aesthetic values of the properties, the best and most effective method of conservation for these items is preventive conservation with minimal intervention and through environmental control to slow down their decay process.

\section{Acknowledgment}

Special thanks and appreciation go to all the centers that helped us in carrying out this project in the relevant period of time, as follows:

Research Center for Conservation and Restoration of Historical Relics (RCCCR)

Cultural Heritage, Tourism and Handicrafts Organization of Zanjan Province

National Museum of Iran

Jam-e Jam Radiology Center in Tehran

Pasteur Institute of Iran

Forensic Medicine Organization of Iran

Oxford University 


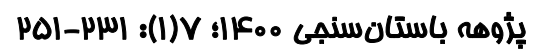

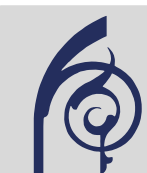

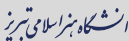

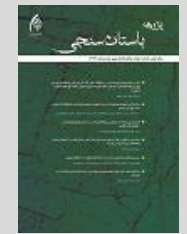

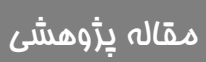

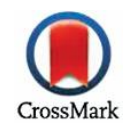

\section{موميايىهاى طبيعى معدن نمك زنجان و}

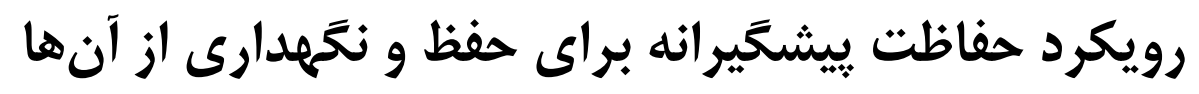

\section{منيزه هاديان دهكردى )}

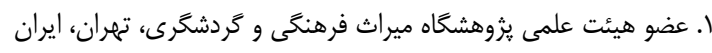

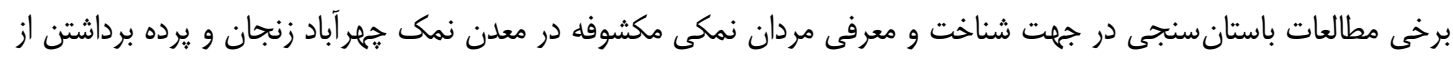

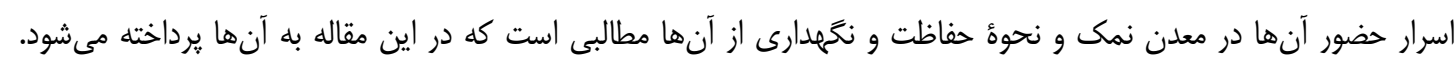

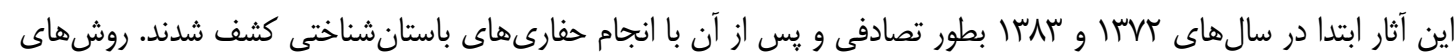

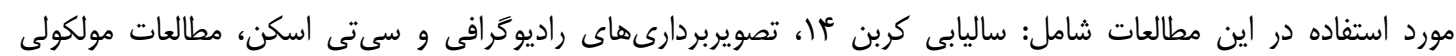

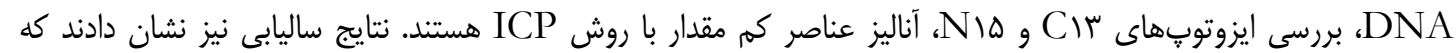

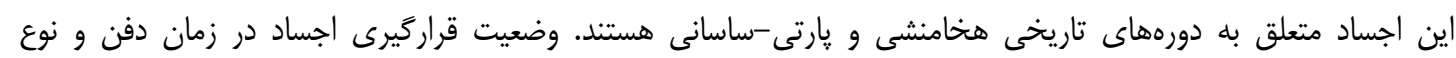

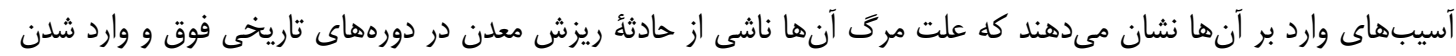

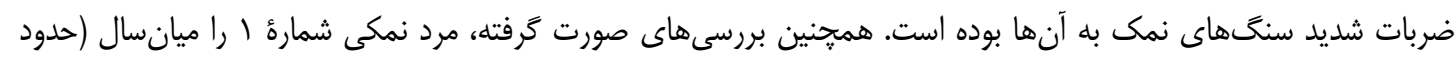

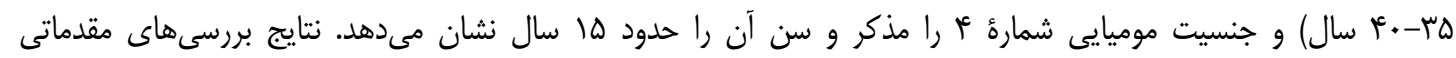

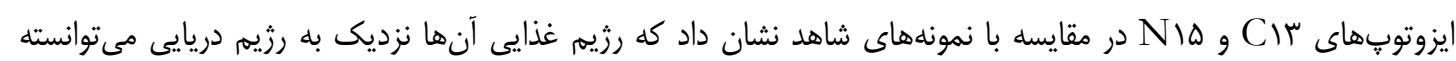

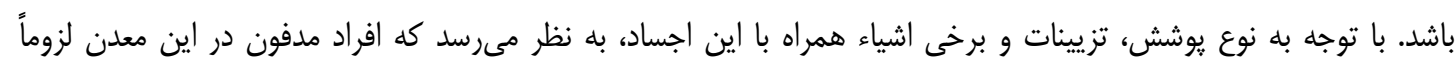

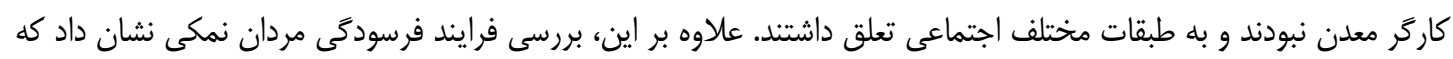

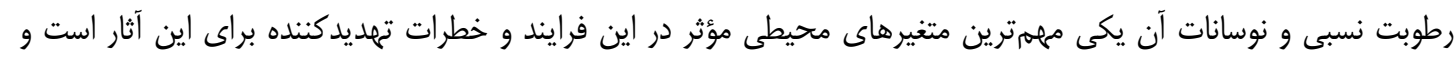

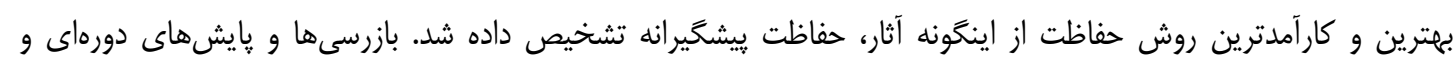

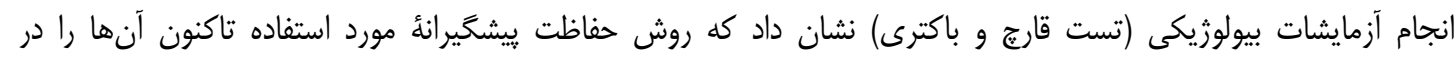

وضعيت ايمن نغاه داشته است.

وازَّان كليدى: مردان نمكى، معلن نمى جِهر آباد، موميايى طبيعى، باستانسنجى، حفاظت يِيشَيرانه

" "نويسنده مسئول مكاتبات: تهران، خيابان امام خمينى، خ سى تير، روبروى ساختمان موزه ملى ايران، شماره ؟ ، يزوهشكاه ميراث فرهنحى و گردشكرى m_hadian@yahoo.com :

C) حق نشر متعلق به نويسنده(كان) است و نويسنده تحت مجوز Creative Commons Attribution License به مجله اجازه مىدهد مقاله خاب شده را با ديكران به اشتراك بكذارد منوط بر اينكه حقوق مؤلف اثر حفظ و بهن انتشار مجنار اوليه مقاله در اين مجله اشاره شود. 
و ييش از شـروع همكارىهـاى تـيهم آلمـانى در ايـن

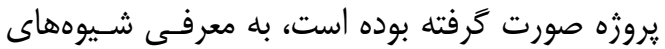

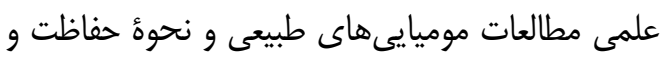

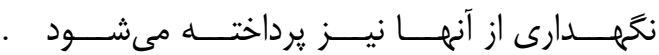

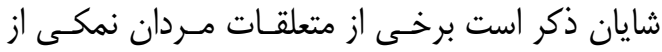

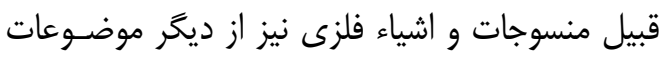

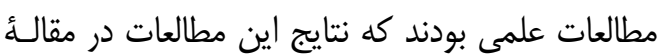
جداگانه ارائه خواهد شد.

\section{r. بيثينة اكتثاف مردان نمكى}

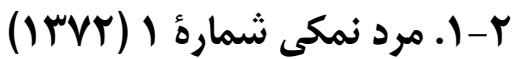

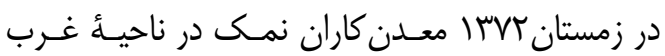

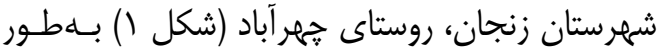

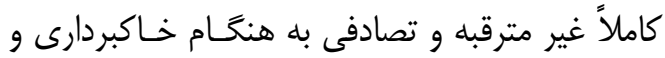
استخراج نمك از معدن زير تِههاى اين منطقه با نيهم

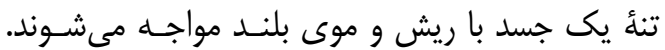
هس از مطلع شدن ادارة كل ميـراث فرهنحـى اسـتان

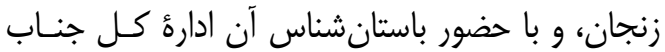

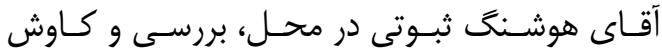

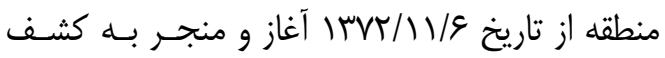

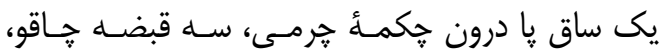

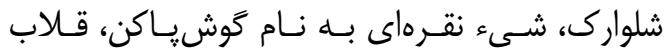

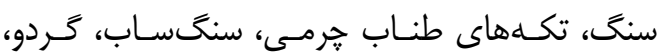

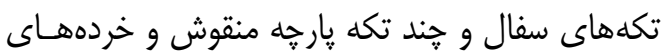
استخوان مىشود. بررسىها و شـواهد باستانشـاخـاختى

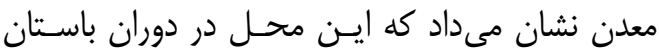

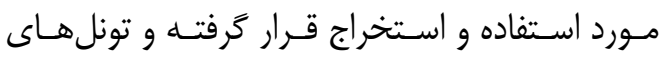

متعددى در داخل معدن نمك كنده شده بود [1].

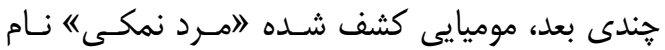

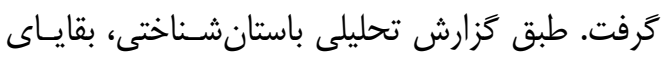

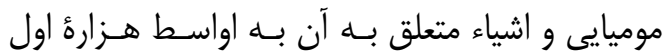
قبل از ميلاد نسبت داده شد [1,4].

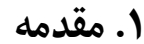

معلن نمك جهر آباد واقع در VD كيلومترى غرب شهر

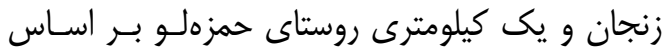

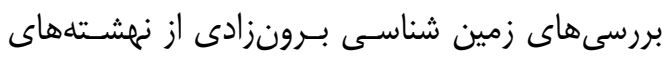

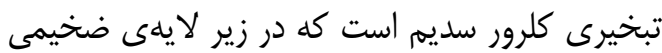

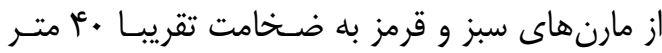

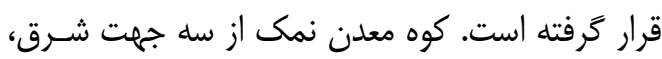
غرب و جنوب به رودخانههاى فصلى مهر آباد، جهر آباد آنهاد

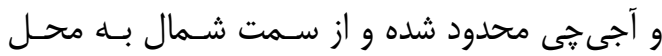

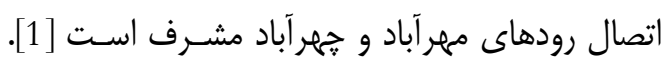
اين معدن در بلندى •هَا متر از سطح آبهاى آزاد و

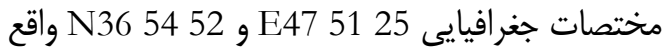
شده است[2].

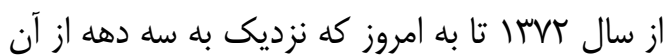

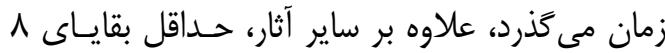

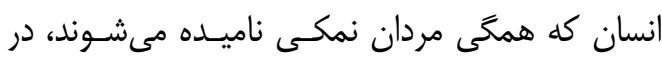

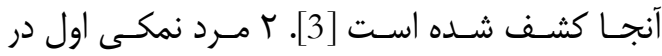

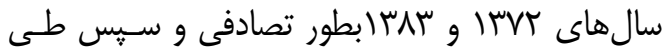

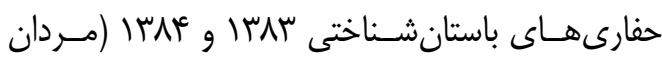

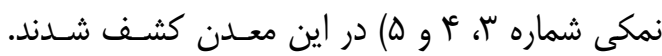
همجنين بقاياى انسانى ديخر) مردان نمكى شمارة

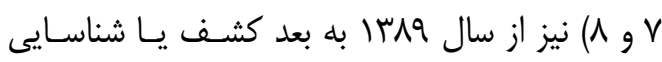

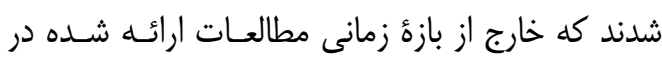
اين مقاله هستند.

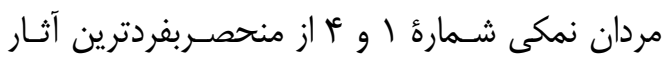

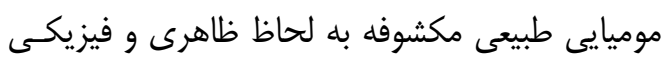
در اين مجموعه هستند. ساير مردان نمكى يا متلاشى

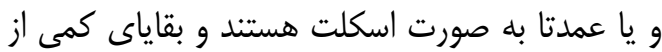

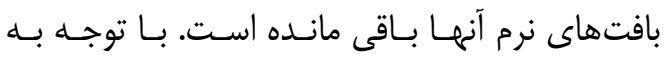

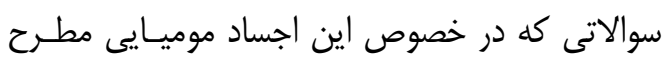

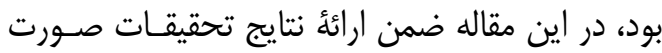
كرفته در جهت شناخت مردان نمكى و يرده برداشت آنت

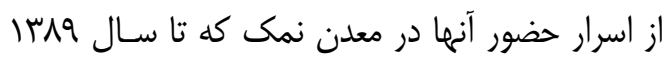




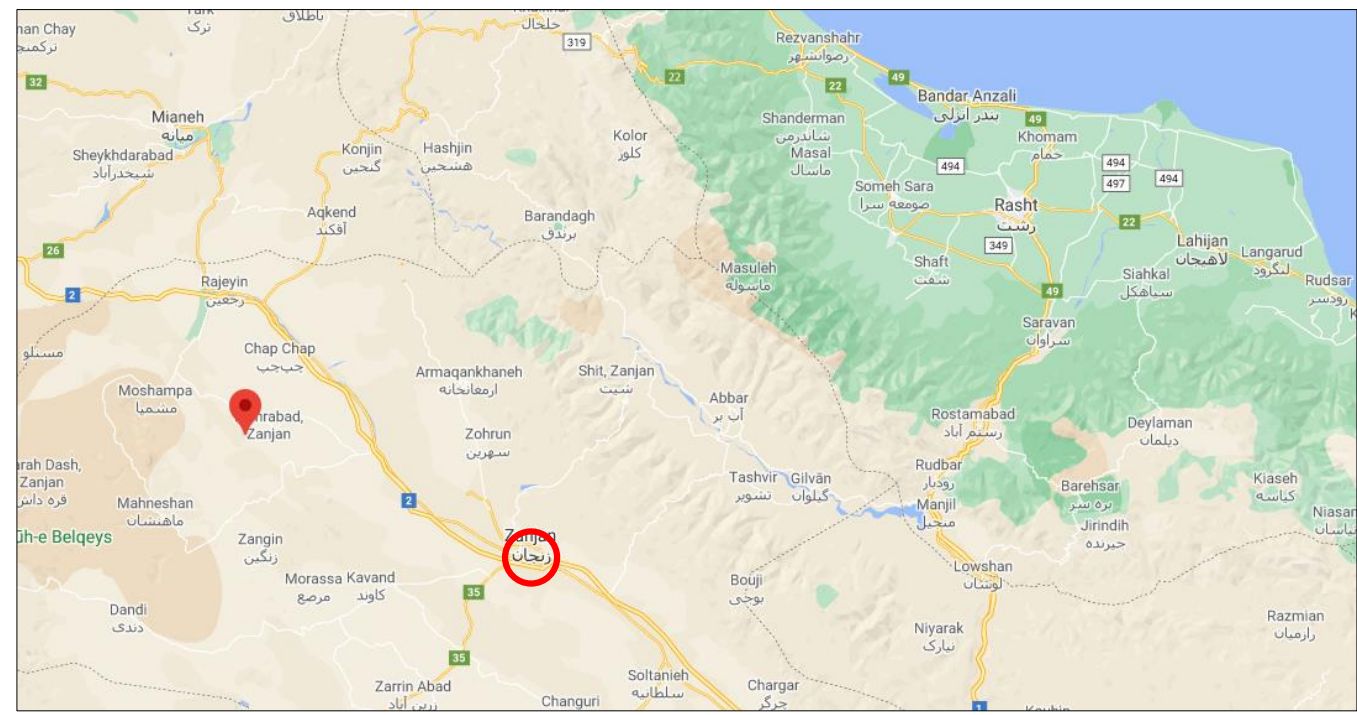

شكل ا: موقعيت روستاى جهر آباد در غرب شهرستان زنجان و درياى مازندران (google earth)

Fig. 1: Chehrabad village situation in the west of Zanjan city and Mazandaran

نيز در دومين فصل حفارى در آذر سال ع آسبا در زيسر

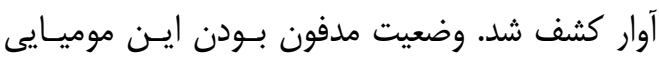

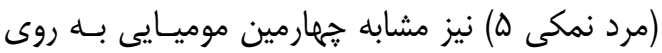

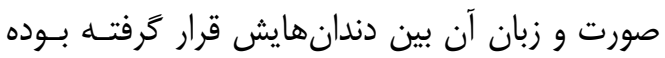

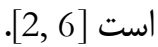

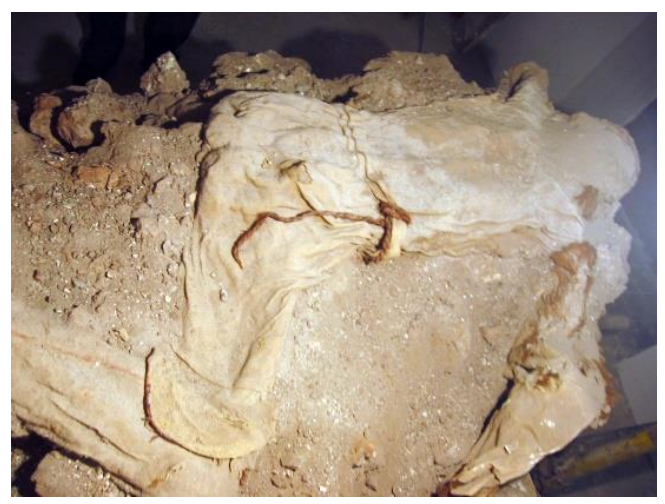

$$
\text { شكل r. مرد نمكى شمارة ז در محل اكتشاف (معدن نمك زمان) }
$$

$$
\text { زنجان (ن) }
$$

Fig. 2: Saltman no. in the site (the Saltmine in Zanjan)

وضعيت جسد سوم و ينجم در محل كشف آنهـا كـه در زير صخرههاى سنگ نمك و آوار بوده است، علت

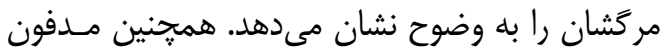

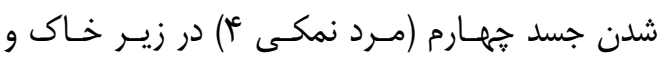

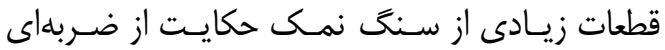

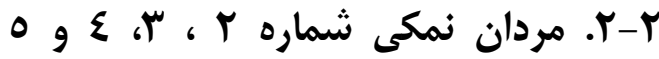

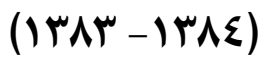

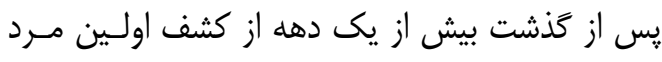

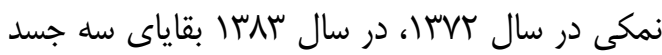

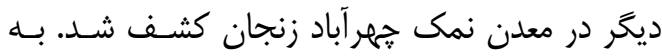

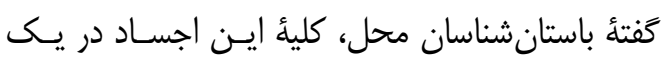

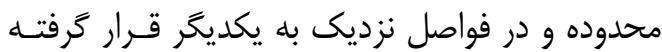

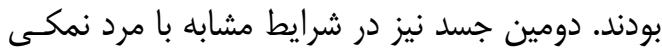

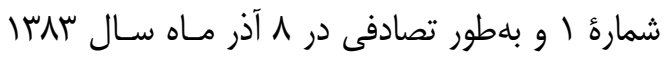

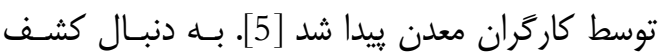
دومسين موميـايى طبيعى در معسدن نمـك جهر آبـاد،

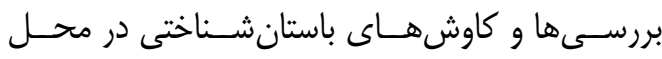

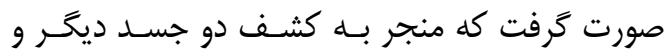

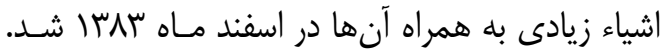

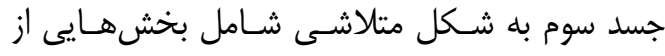
بافتهاى استخوانى و نسوج نرم و يوشش آن شـامل شئل

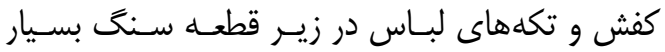

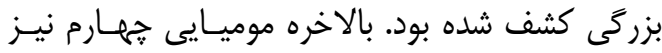
طى حفارىهاى انجام شده به طور ناباورانـهاى نسـبـاً

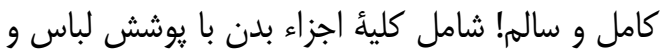

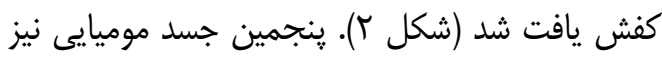

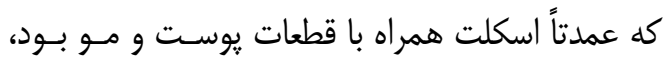




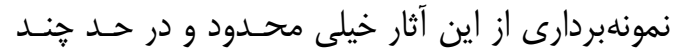

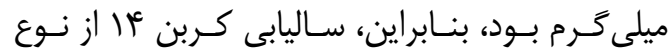

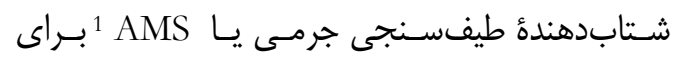
اينكار مناسب تشخيص داده شد [8]. به ايـن منظـور

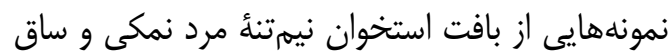

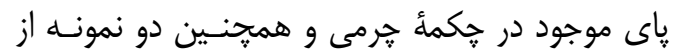

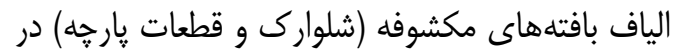

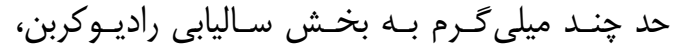

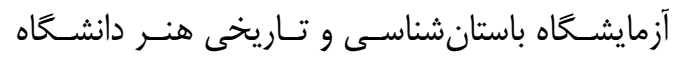
آكسفورد در انخلستان ارسال شد.

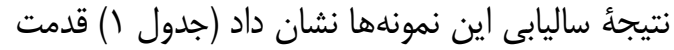
اين مجموعه به دوران اواخر هارتى و اوايل ساسانى يان إنهان

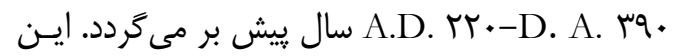
نتيجه با نظرات باستانشناسى متفاوت بود. طبق نظر

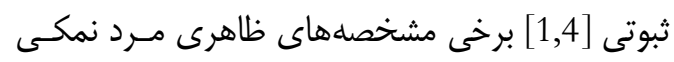

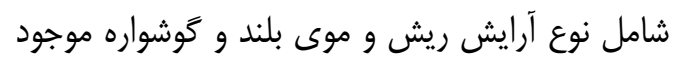
در كوش جِ و همجنين نوع يوشش آن كه شلوارى

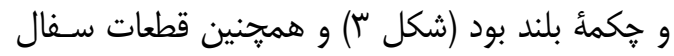

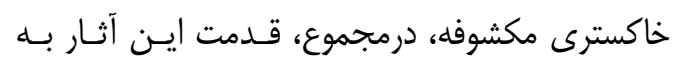
دوران هخامنشى نسبت داده شد.
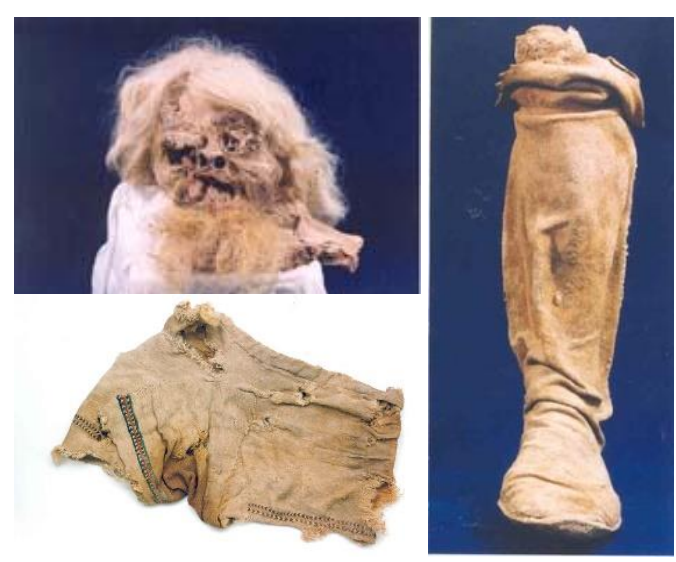

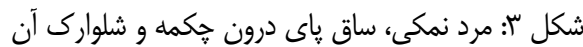
Fig. 3: Saltman, the foreleg inside a leather boot and its short trouser
مى كنـــــــهـ منجــر بــه افتـادن آن بــه روى شـكمم و بالاخره مرى اسفبار آن شده بوده اسـت. نحــوة قـرار

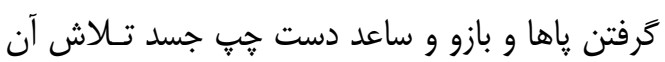
را براى بلند شدن يا بـالا رفـتن از جـايى در لحظـات

$$
\text { قبل از مرى مىرساند. }
$$

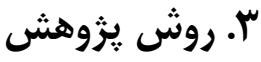

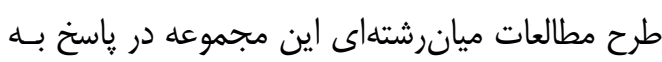
جند سئوال اساسى شكل گَرفت. اين سئوالات عبارت

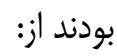

ו- اين مجموعه متعلق به جند سال يِيش است؟

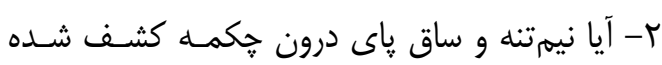

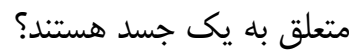
ץ- علت مرگ مردان نمكى خه به بوده است؟

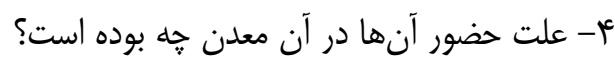
ه- سن و جنسيت جهارمين موميـيى مكشـوفه جـهـ

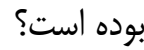
צ- جَكونه مى توان آثار موميايى مكشوفه را حفاظت و

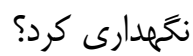
در اين ارتباط از روشهاى آزمايشعاهى ساليابى كربن

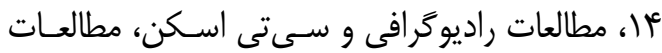

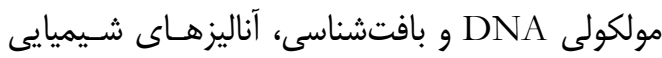

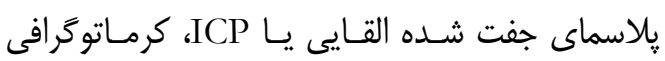

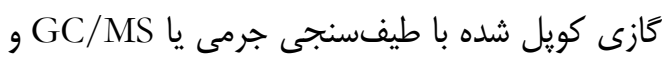
مطالعات ميكروبيولـوزى شناسـايى قـارج و بـاكترى استفاده شد. بازرسى هاى بصرى و يايش دورهاى آثاثل بخش ديخرى از اين تحقيق بوده است.

\section{ع. نتايج و بحث}

\section{ع- (. مطالعات باستانسنجى مردان نمكى}

\section{1-1 - - (-). ساليابى مجموعه}

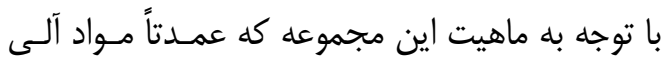

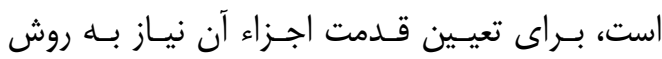

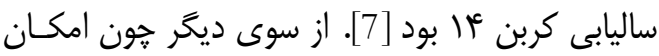


جدول (: قدمت نمونههاى مورد مطالعه مرد نمكى شماره |

Table 1: Date of the Saltman samples

\begin{tabular}{|c|c|c|c|}
\hline No. & $\begin{array}{c}\text { نمونهه } \\
\text { Sample }\end{array}$ & $\mathrm{BP}^{2}$ & $\mathrm{BC} / \mathrm{AD}$ \\
\hline 1 & $\begin{array}{l}\text { استخوان نيهتنه مرد نمكى } 1 \text { half body bone } \\
\text { Saltman1 }\end{array}$ & $1800 \pm 55$ & \multirow{4}{*}{ A.D. $220-390$} \\
\hline 2 & $\begin{array}{l}\text { استخوان زانوى مرد نمكى } 1 \text { knee bone } \\
\text { Saltman1 }\end{array}$ & $1625 \pm 50$ & \\
\hline 3 & $\begin{array}{c}\text { شلوارك مرد نمكى } 1 \text { Short trouser } \\
\text { Saltman } 1 \text {. }\end{array}$ & $1860 \pm 55$ & \\
\hline 4 & 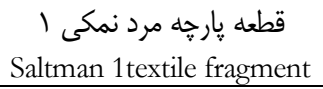 & $1745 \pm 50$ & \\
\hline
\end{tabular}

يوستين مرد نمكى شماره أو يكى نمونه يوست مـرد

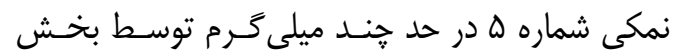

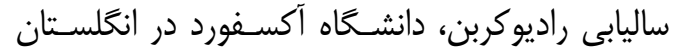

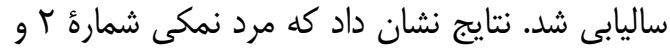

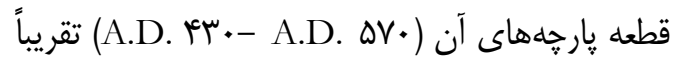

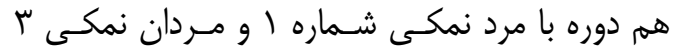

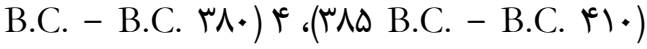

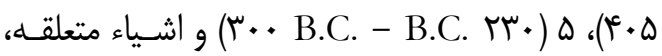
مربوط به دورة هخامنشى هستند.
همانند ساليابى مرد نمكى شمارة ا براى تعيين قدمتِ

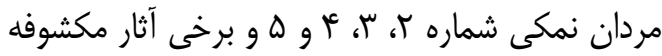
با آنها كه ماهيت آلى داشتند از روش ساليابى كـربن

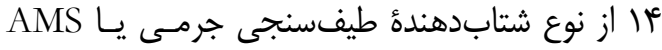

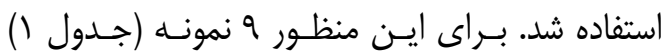

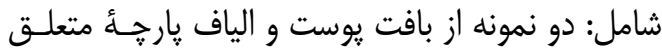

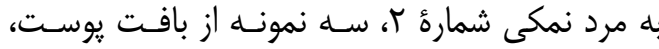

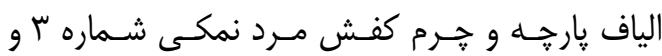

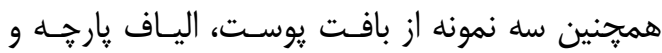

جدول r: قدمت نمونههاى مورد مطالعه مردان نمكى

Table 2: Date of Saltmen no. 2-5 samples

\begin{tabular}{|c|c|c|c|}
\hline No. & $\begin{array}{l}\text { نمونه } \\
\text { Sample }\end{array}$ & $\mathrm{BP}$ & $\mathrm{BC} / \mathrm{AD}$ \\
\hline 1 & 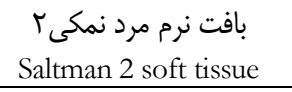 & $28 \pm 1589$ & \multirow{2}{*}{ A.D. $430-570$} \\
\hline 2 & $\begin{array}{l}\text { لباس مرد نمكى } 2 \text { textile } \\
\text { Saltman } 2 \text { te }\end{array}$ & $1829 \pm 30$ & \\
\hline 3 & $\begin{array}{l}\text { بافت نرم مرد نمكىى } 3 \text { soft tissue } \\
\text { Saltman } 3 \text { soft }\end{array}$ & $2336 \pm 29$ & \multirow{3}{*}{410 B.C. - B.C. 385} \\
\hline 4 & $\begin{array}{l}\text { لباس مرد نمكى } 3 \text { textile } \\
\text { Saltman } 3 \text { tex }\end{array}$ & $2304 \pm 29$ & \\
\hline 5 & 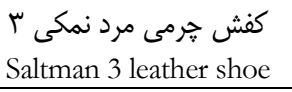 & $2376 \pm 31$ & \\
\hline 6 & $\begin{array}{l}\text { بافتهاى مرد نمكى } 4 \text { باف } 4 \text { soft tissue } \\
\text { Saltman }\end{array}$ & $29 \pm 2262$ & \multirow{3}{*}{405 B.C.-B.C. 380} \\
\hline 7 & $\begin{array}{l}\text { يوستين مرد نمكى } 4 \text { fur cloak } \\
\text { Saltman } 4 \text { fur }\end{array}$ & $2355 \pm 29$ & \\
\hline 8 & $\begin{array}{l}\text { لباس مرد نمكىى } 4 \text { extile } \\
\text { Saltman } 4 \text { texte }\end{array}$ & $2358 \pm 28$ & \\
\hline 9 & $\begin{array}{l}\text { ه يوست مرد نمكى شماره } 1 \text { soft tissue } \\
\text { Saltman } 5 \text { sof }\end{array}$ & $28 \pm 2286$ & 300 B.C.-B.C. 230 \\
\hline
\end{tabular}




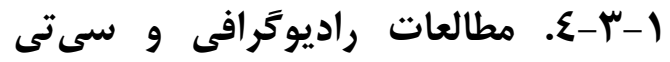

اسكن

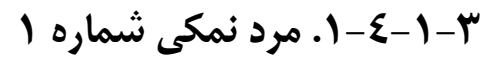

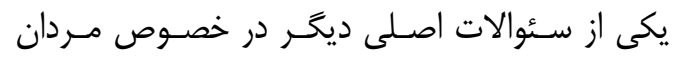

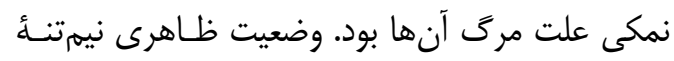

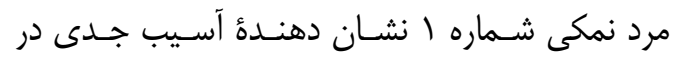

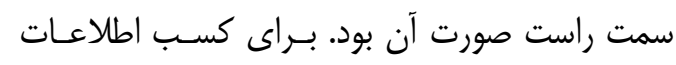

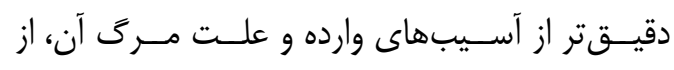

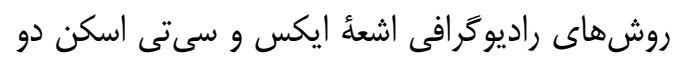

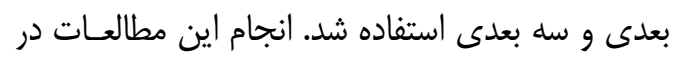

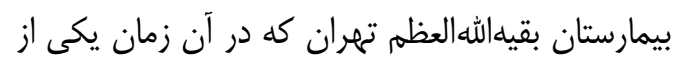

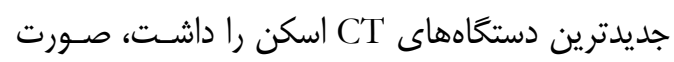

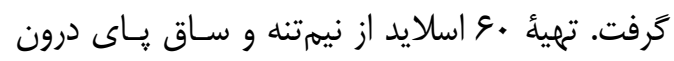

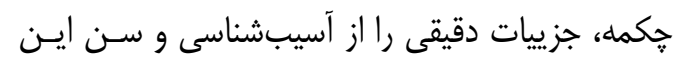
موميايى در اختيار قرار داد (شكل أ) جناء).

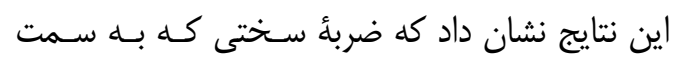

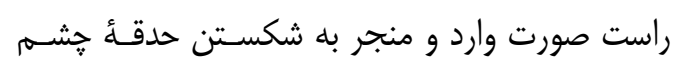
مرد نمكى نيز شده، سبب مرى او بوده است. موقعيت

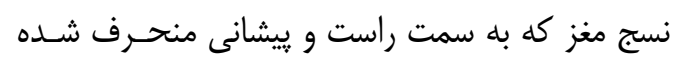

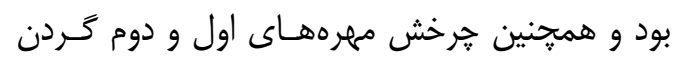

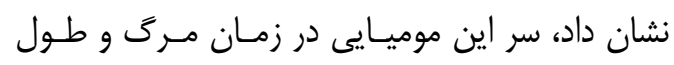

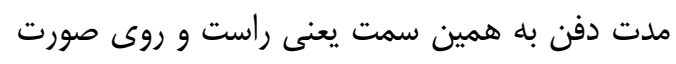

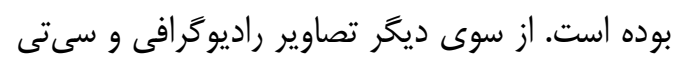

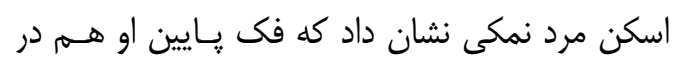

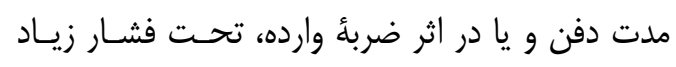
بيرون زده بوده است.

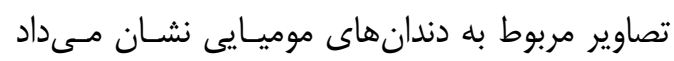

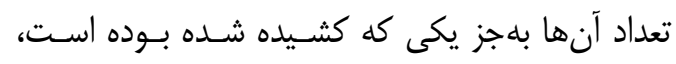

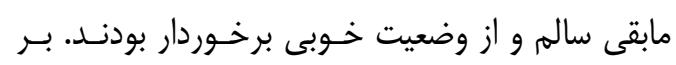

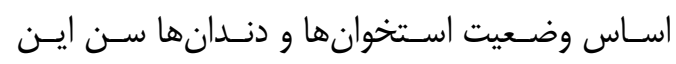

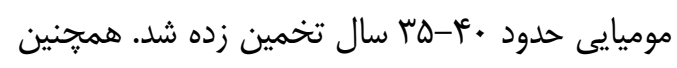

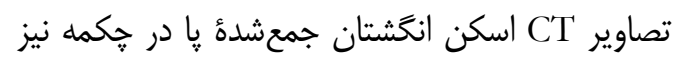

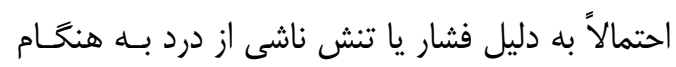
مرگ بوده است [13].
| I-Y-Y. مطالعات ملكولى DNA مرد نمكى

شماره

در قاسخ به سئوال مطرح در خصوص ارتبـاط نيمتنـــ مرد نمكى و ساق پاى درون خكمه مكشوفه كـه آيـا

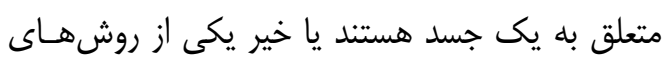

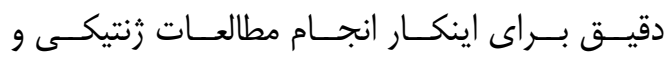

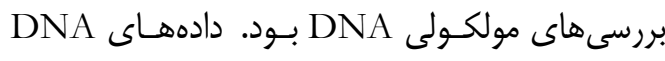

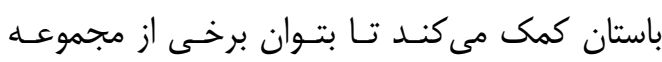

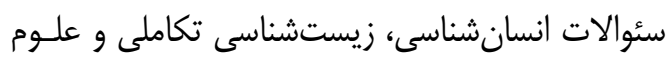

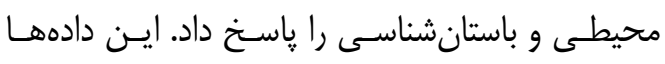

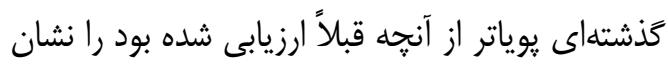

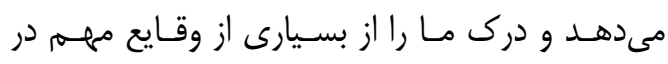

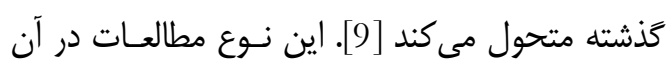

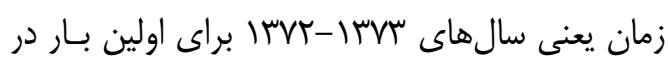

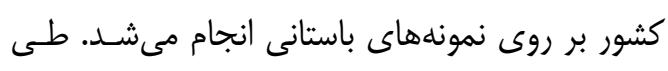

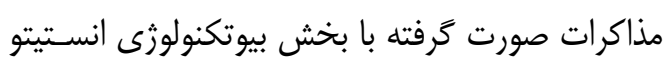

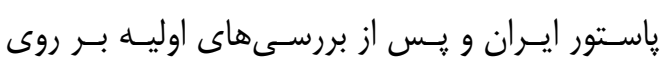

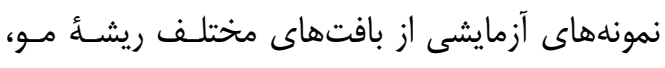

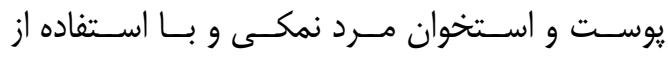

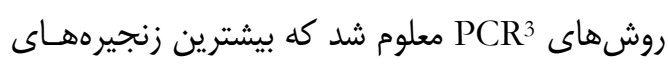

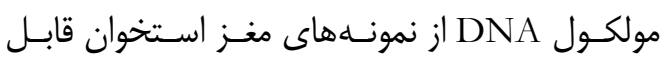

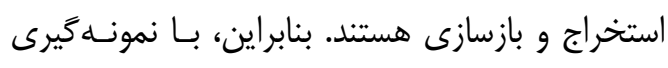

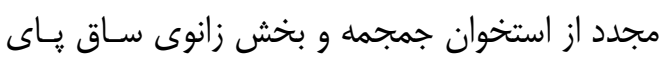
درون جكمه مطالعات دقيقتر و كاملترى انجام شـدـ.

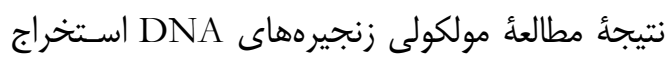

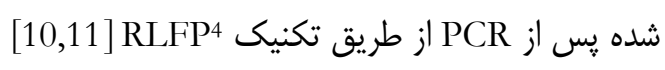

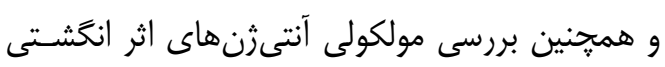

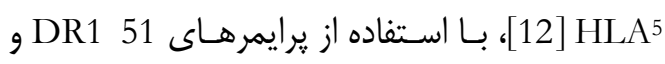
DR2 52

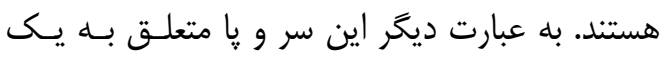
جسد بودهاند. 

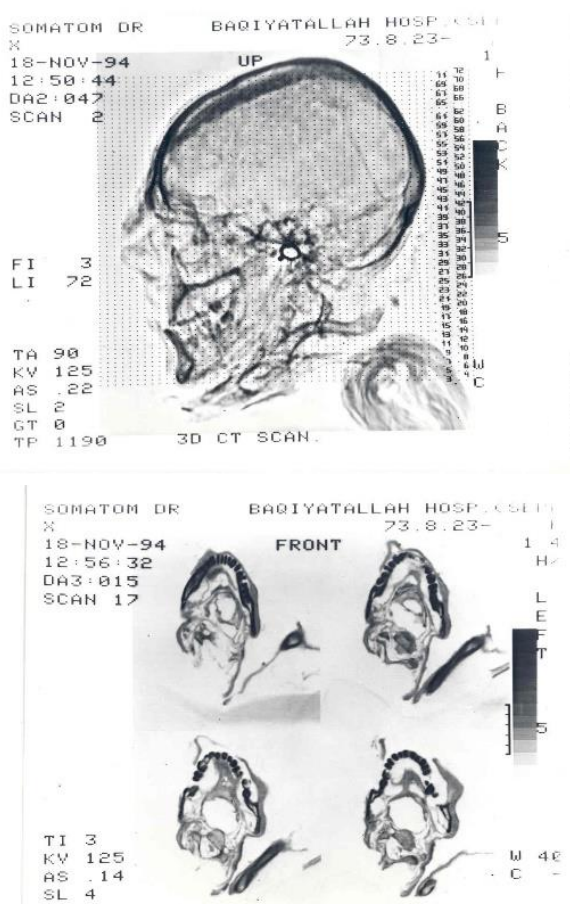

30 CT SCAH

شكل ع: تصاوير سى تى اسكن نيم تنه و ساق ياى مرد نمكى شماره ا
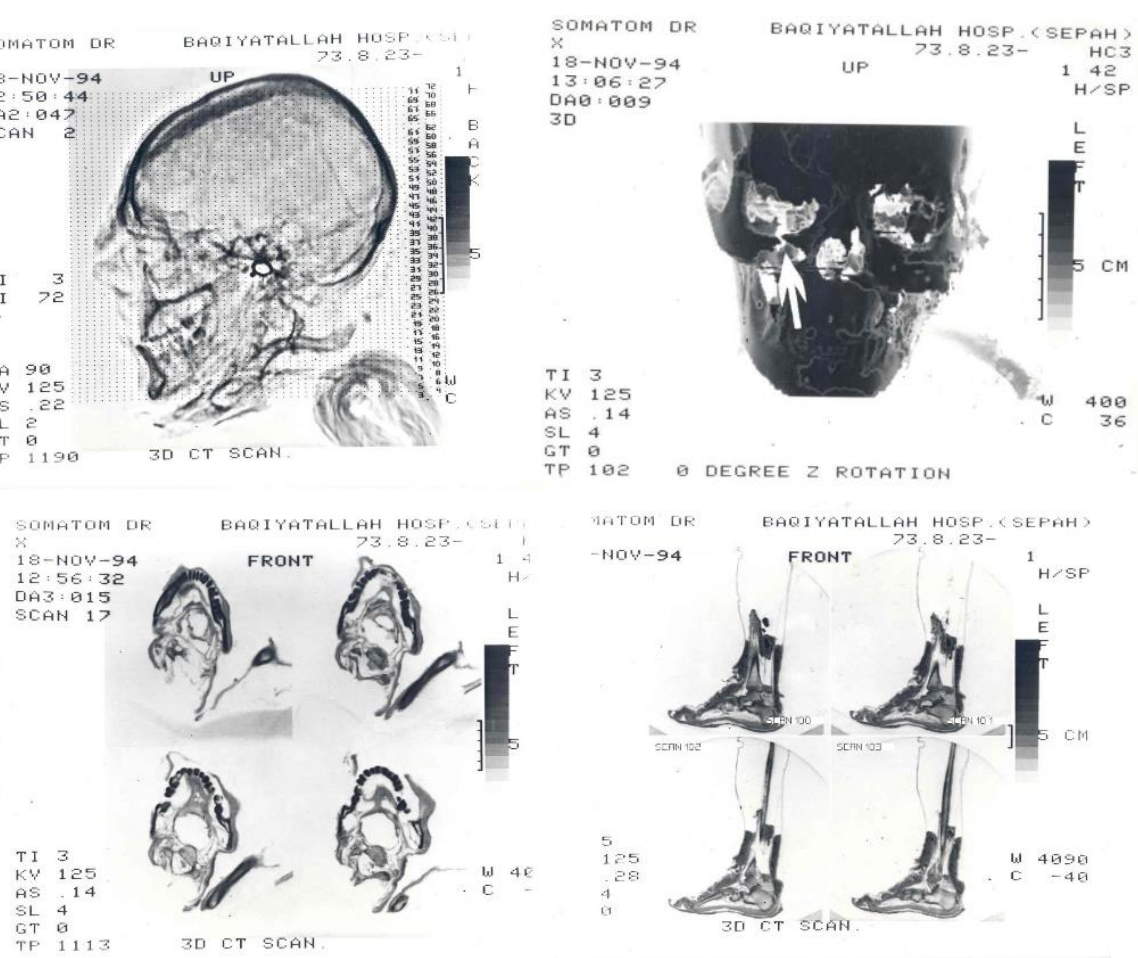

WATOM DR EAQIYATALLAH HOSP. (SEPAH)

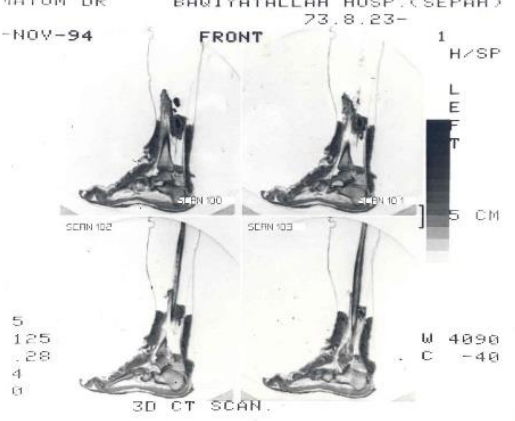

Fig. 4: CT scan images of the Saltman No. 1 and its foreleg inside the leather boot

مشاهدة شكستخى هاى متعدد در كل بلن و همجنين شكستخى هاى عرضى در اسـتخوان هاى بلنـد نشـان

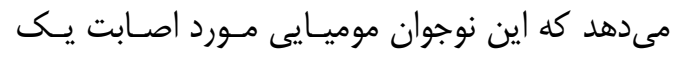

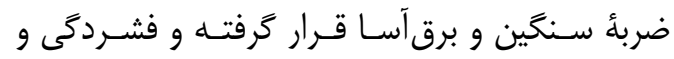

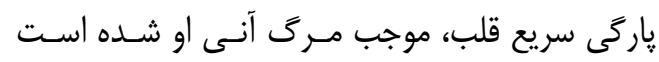

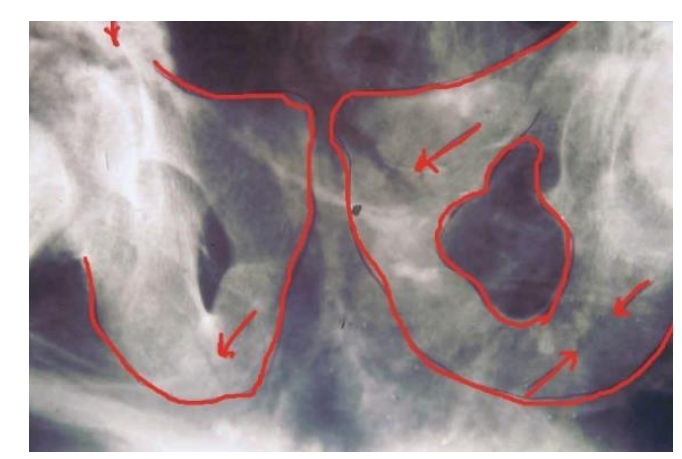

شكل ه: تصوير راديوگًافى استخوان لخن مرد نمكى شماره ع كه

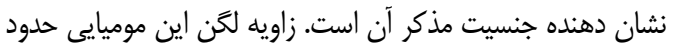

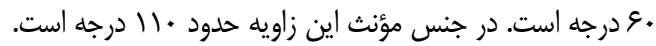

Fig. 5: Pelvis X-ray of the saltman 4 which shows its gender to be male. This angle is about 60 degrees (proving it to be a male). In females it is about 110 degrees.

\section{(}

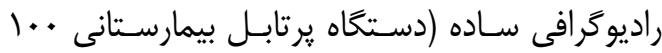

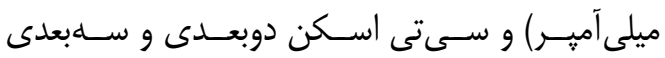

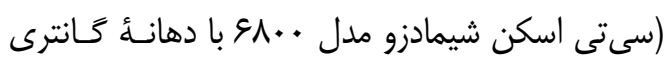

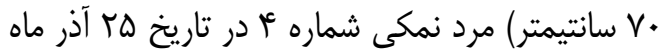
أ

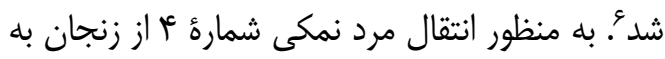

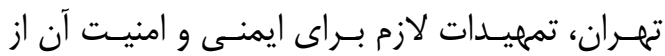

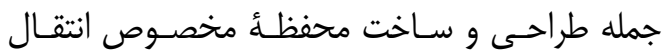
صورت كرفت كه در ادامه جزييات بيشترى از آن ذكر آنس

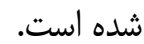
نتايج تصويربردارى هاى اشعُ ايكس نشان داد با با توجه

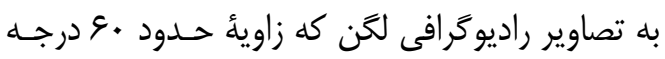

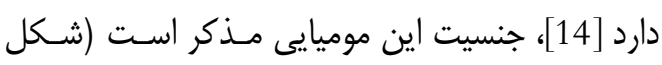

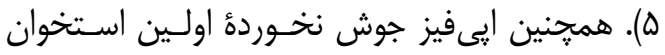

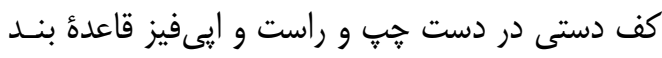
اول انگشت شست، سن آن را بين وعا-ها سال نشان

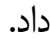




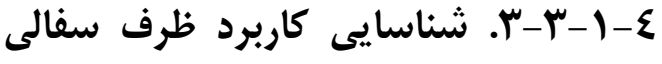

\section{مرد نمكى شماره ع}

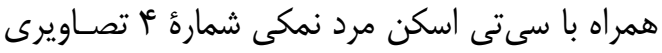

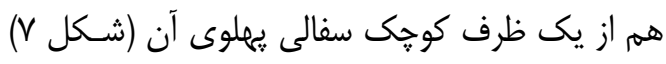

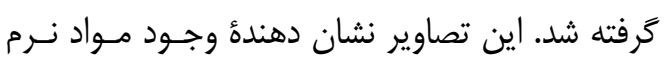

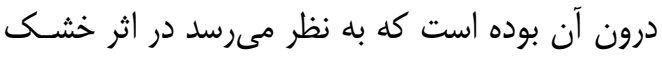
شدن ترك خورده باشـــ كـاربرد ايـن ظـرف و و مـواد

درون آن يكى ديخر از سئوالات مطرح بوده است.

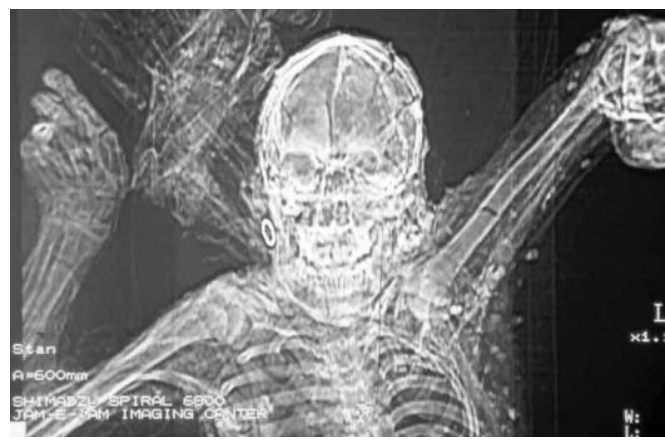

شكل ؤ شكستخى هاى متعدد در سر، سينه و بازوان مرد نمكى

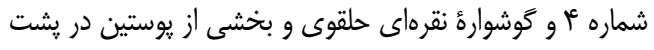
سر آن حلن

Fig. 6: Several fractures in head, chest and arms of the Salt-man no.4 with a silver ring on the right ear and a part of animal skin behind his head

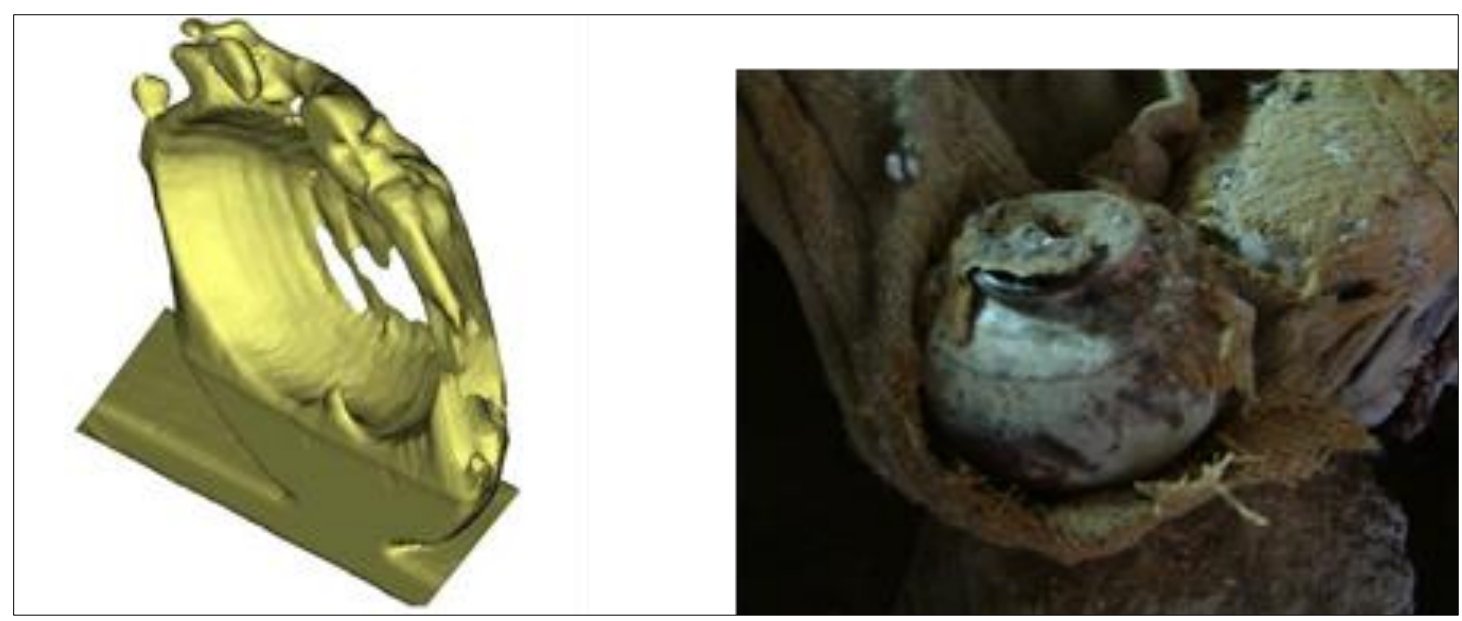

شكل Y: ظرف سفالى مرد نمكى شماره ( (راست) و سى تى اسكن سه بعدى آن (ج)

Fig. 7: pottery visel of Saltman no. 4 (right) and its 3D CT scan (left)

نمكى شمارهُ ك و ه انجـام شـــ نتـايج ايـن آزمـايش

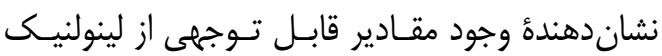

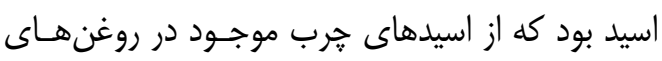

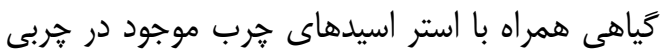

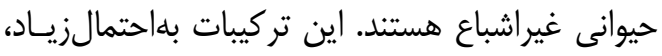

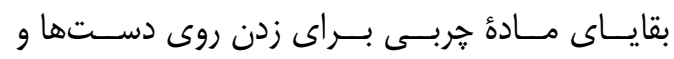
جلوگيرى از آسيب نمك بوده است [16]. البته ناگفته نماند كه شناسايى مواد درون ظرف سـفالى همجِنـان

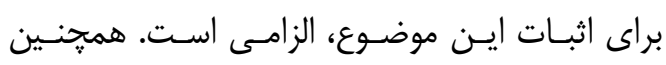

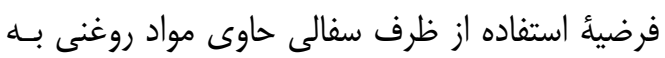
عنوان ييهسوز جهت روشنايى نيز وجود دارد.
ع-1-ع. آسيبشناسى :وست دست مردان نمكى

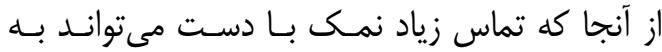

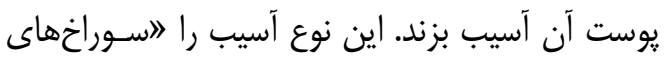

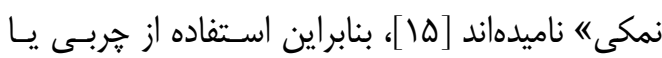
مواد روغنى مىتوانـد يكى از راههـاى ييشـيَيرى از

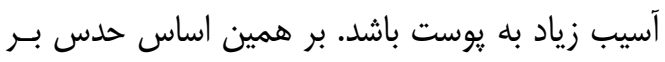

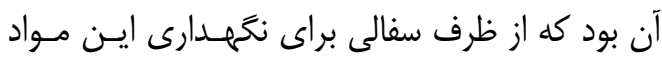
استفاده مى شده است. براى اثبات اين نظريه آزمـايش

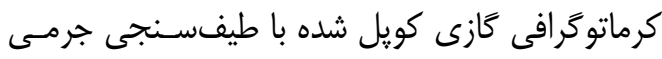

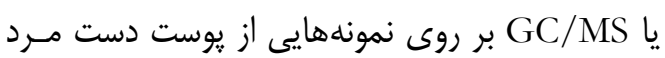


مربوط به رنخ اولية موهاى مرد نمكى باشد. از سوى

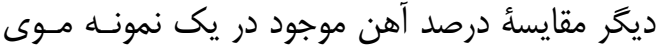

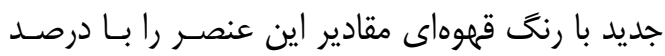

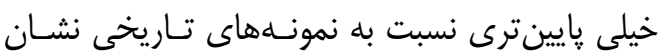

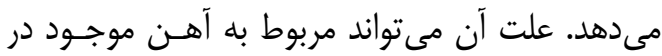

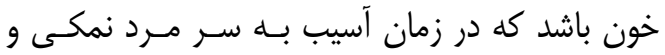

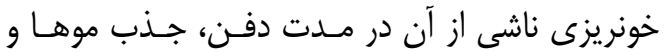

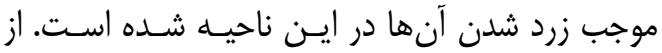
سوى ديخر و طى بررسى ظاهرى موها كـه لابـهلاى

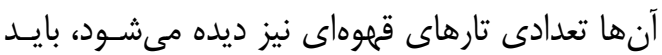
كفت كه سفيد بودن موها نمى توانسته مادرزادى باشد.

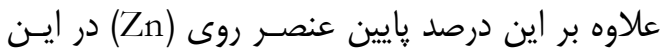

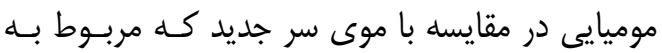

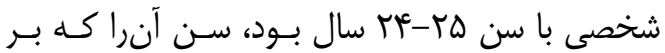
اساس مطالعات CT اسكن حسدود •+ سـال تخمـين

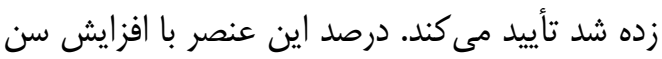
افراد در بلن كاهش مىيابد [17].
ع-1-0. آناليز عنصرى موهاى مرد نمكى

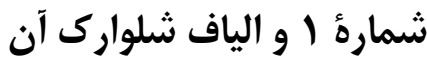
عناصر كم مقدار موجود در موها نشاندهندة اطلاعات

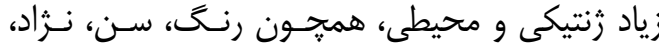

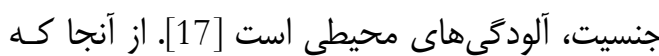

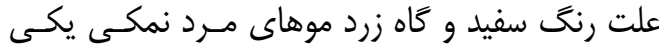
ديكر از موضوعات مورد سئوال بود، به همين لحاظ و

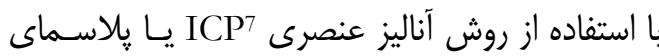
جفت شده القايى مدل ARL در مركز تحقيقـات آثار

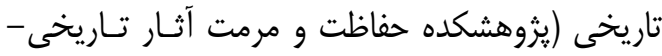

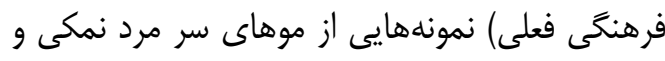

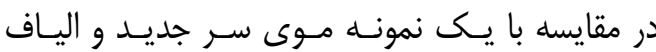
شلوارك مورد بررسى قرار گرفتند (جدول سَ).

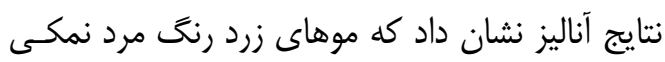

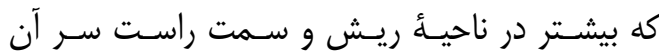

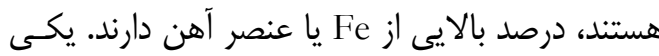

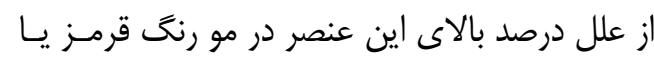

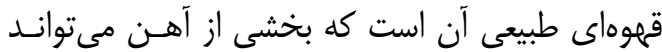

جدول ؟ : ميزان عناصر شناسايى شده در تار مو و الياف شلوارك مرد نمكى در مقايسه با يك تار موى جديد قهوهاى (ppm) Table 3: The amount of elements detected in the hair, and fibers of salt man short trouser compared to a new brown hair

\begin{tabular}{|c|c|c|c|}
\hline $\begin{array}{l}\text { تار موى قهوماى جديد } \\
\text { New brown hair }\end{array}$ & $\begin{array}{c}\text { الياف شلوارك مرد نمكىى1 fhort trouser fiber } \\
\text { Saltman1 short }\end{array}$ & $\begin{array}{l}\text { تار موى مرد نمكىى } \\
\text { Saltman1 hair }\end{array}$ & $\begin{array}{c}\text { عنصر } \\
\text { element }\end{array}$ \\
\hline 3.1 & 6.6 & 108 & $\mathrm{Ag}$ \\
\hline - & 22.5 & 37 & $\mathrm{Au}$ \\
\hline- & 1270 & 268 & $\mathrm{Al}$ \\
\hline- & - & - & As \\
\hline 30.6 & 47 & - & $\mathrm{Bi}$ \\
\hline 30.2 & 0.8 & 4.2 & $\mathrm{Cu}$ \\
\hline- & $\begin{array}{l}0.8 \\
\end{array}$ & 5.6 & $\mathrm{Cr}$ \\
\hline 281.1 & 687 & 380 & $\mathrm{Fe}$ \\
\hline- & 490 & 480 & $\mathrm{~K}$ \\
\hline- & 595 & 1230 & $\mathrm{Na}$ \\
\hline 73.1 & 6.6 & 17 & $\mathrm{~Pb}$ \\
\hline 4.0 & - & - & Sn \\
\hline 196 & 53 & 183.5 & $\mathrm{Zn}$ \\
\hline
\end{tabular}

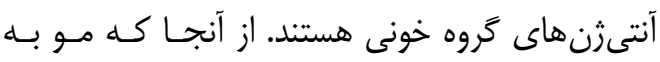

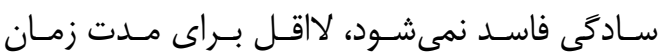

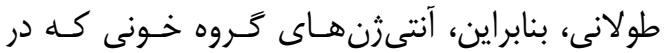

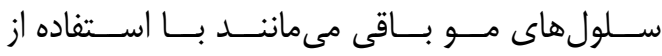

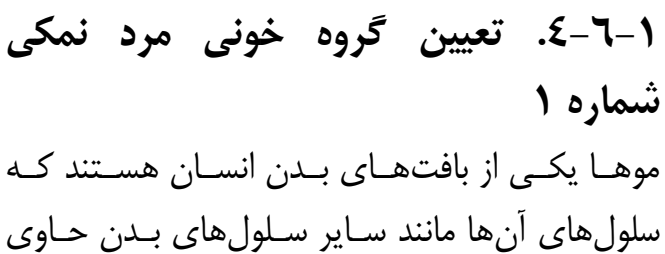

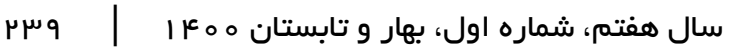


اطلاعات مفيدى را در خصوص شيوه زندگى افـراد از

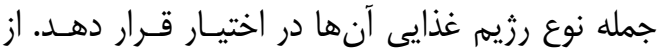

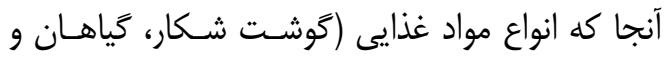
آبزيان) در طى جند سال مىتواند با مقادير خاصى از از هر يك از ايزوتوبهـاى فـوق در كـلازن بافتهـاى

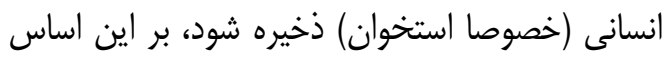

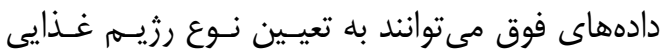

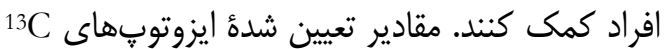

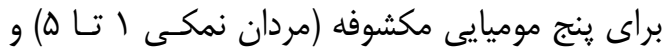

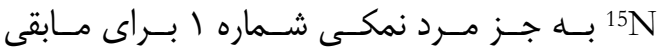
اندازهكيرى شد (جدول

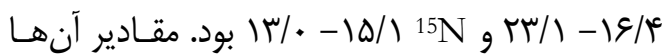
در مقايسه با نمونههاى شـاهد [18] همـانطور كـه در

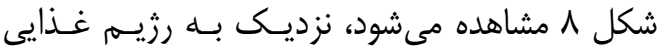

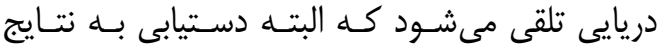

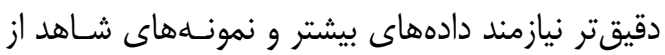
افراد بومى مناطق مختلف مربوطه است [116]. شكل م: نمودار سطوح ايزوتوڤهاى بايدار رثيم غذايى [18] و و

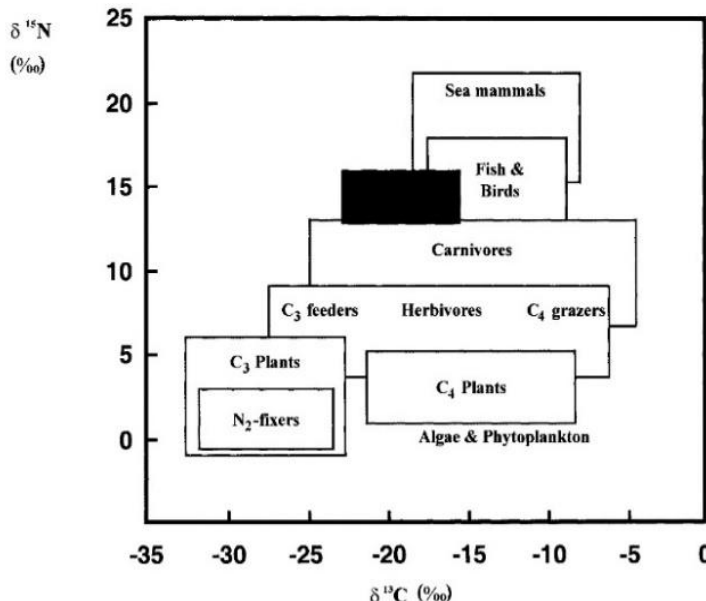

مقايسه با دادهاى مربوط به مردان نمكى (مستطيل سياه) Fig. 8: Stable isotope trophic level [18] with data from Saltmen (black rectangle)

\section{ع-r. اقدامات حفاظتى مردان نمكى}

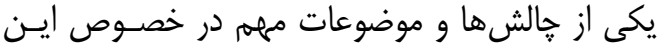

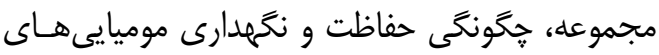

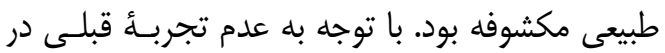

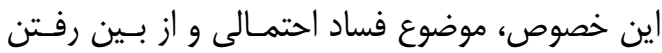

آنتىســـمهاى ضــ A و B و ايجــاد آكلوتيناسـيون

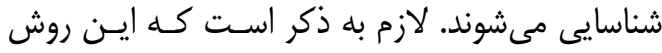

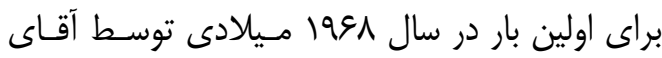

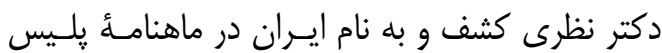
اينتريل ثبت شده است. بر اسـاس مطالعـات صـورت كرفته توسط بخش سرولوزى سازمان يزشكى قانونى

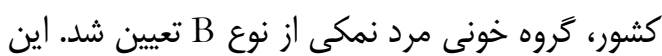

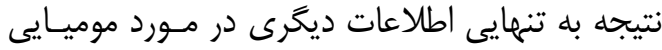

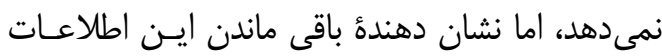

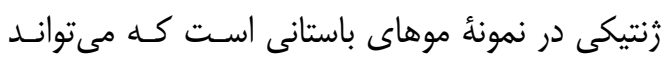
ارتباطات خانوادگى در موارد خاص را روشن كند.

\section{ع-1 - V- مطالعات مقدماتى نوع رزيم غذايى

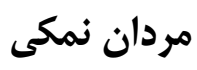

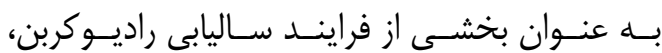

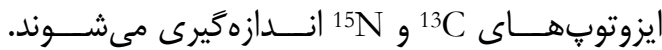

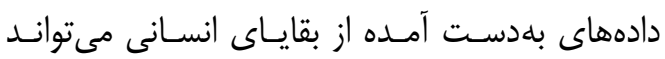

جدول ث: مقادير ايزوتوضهاى

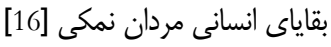

Table 4: Values of ${ }^{13} \mathrm{C}$ and ${ }^{15} \mathrm{~N}$ isotopes measured in human remains of salt men [16]

\begin{tabular}{|c|c|c|c|}
\hline No. & $\begin{array}{l}\text { نمونd } \\
\text { Sample }\end{array}$ & $\begin{array}{c}{ }^{13} \mathrm{C} \\
\text { delta } \\
\%\end{array}$ & $\begin{array}{c}15 \mathrm{~N} \\
\text { delta } \\
\%\end{array}$ \\
\hline 1 & $\begin{array}{l}\text { بافت يوست مرد نمكى } 1 \text { soft tissue } \\
\text { Saltman1 }\end{array}$ & -16.4 & - \\
\hline 2 & $\begin{array}{l}\text { بافت يوست مرد نمكى } 1 \text { افلft tissue } \\
\text { Saltman1 soft }\end{array}$ & -17.1 & - \\
\hline 3 & 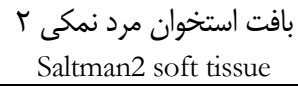 & -20.4 & 13 \\
\hline 4 & 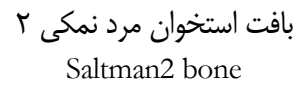 & -18.2 & 14.4 \\
\hline 5 & 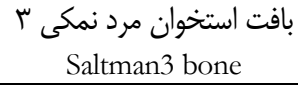 & -20.3 & 13.7 \\
\hline 6 & $\begin{array}{c}\text { بافت استخوان مرد نمكى } \\
\text { Saltman4 bone }\end{array}$ & -23.1 & 14.7 \\
\hline 7 & $\begin{array}{c}\text { بافت استخوان مرد نمكى } \\
\text { Saltman4 bone }\end{array}$ & -20.2 & 15.1 \\
\hline
\end{tabular}


حشرات و نوزاد آنها با تتذيه از بقايـاى انسـانى در از

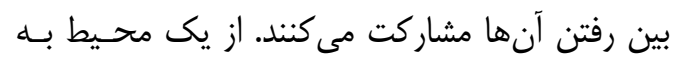

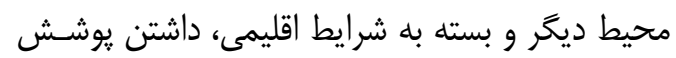

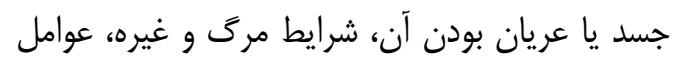

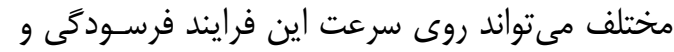
فساد آن تأثير داشته باشد [19].

\section{E-Y-Y-Y. شر ايط محيطى رشد و بقاى عوامل}

بيولوزيك

همانطور كه در بالا اشاره شد يكى از عوامل تجزئ

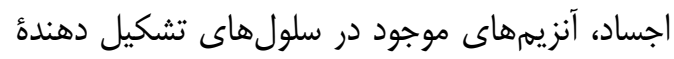
بافتهاى موجود زنده هستند كه فعاليت آنها تنها در حضور آب عملى است. بنابراين حذف آب يا رطوبت از محيط، سبب توقـف فراينــ تجزيـــ سـلول مى شــود. همجنين اهميت رطوبت يا آب موجـود در محـيط يـا فيـا بافتهاى اجساد براى ادامٔٔ حيات باكترىها و قارجها

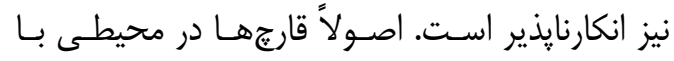

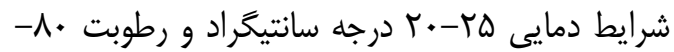

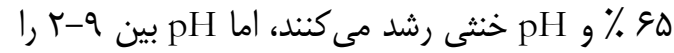

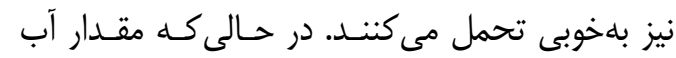

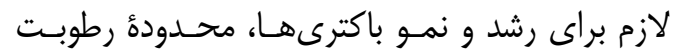

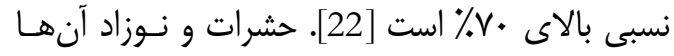

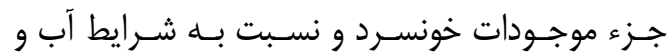

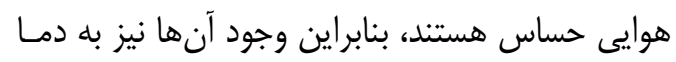

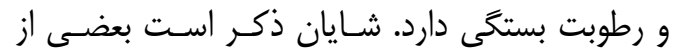

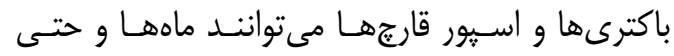

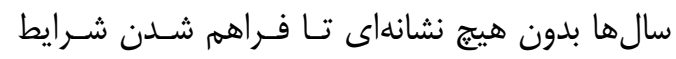
رشد، بلهور نهفته زنده بمانند.

\section{ץ-ץ-זع. مطالعات بافتشناسى}

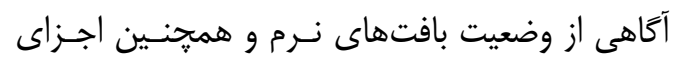

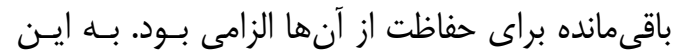
منظور بخشى از يوست مـرد نمكسى شـماره ا مـورد

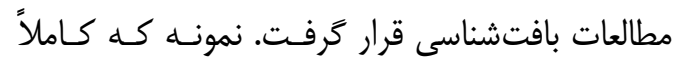

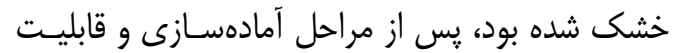

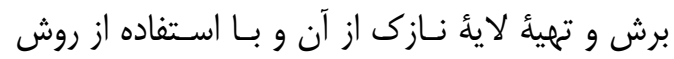

اين موميايىها يكى از دغدغههاى مســؤلان ميـراث

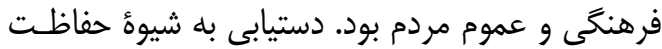

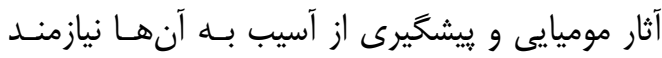
انجام مطالعات دقيق علمى بود كه در ابتدا مىبايست فرايند فرسودگى اين آثار مورد بررسى قرار مى گرَفت.

\section{ع-ץ-1. فرايند فرسودَى و علت فساد بقاياى انسانى}

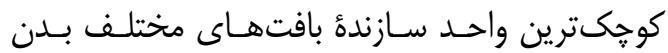

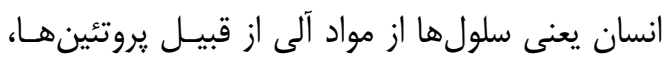

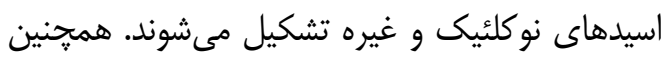

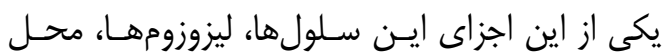

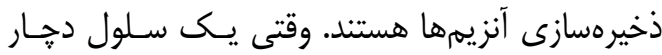

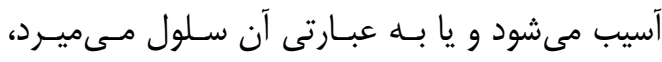

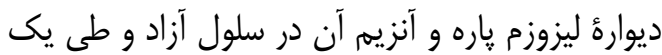
واكنش شيميايى سبب تجزيه و هضم سلول مى شـود.

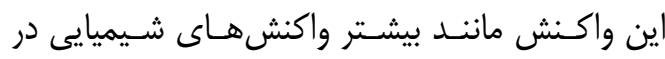

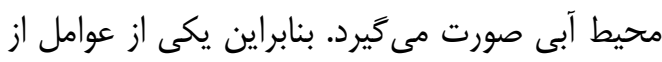

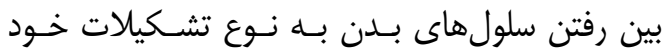

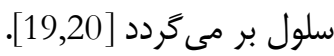

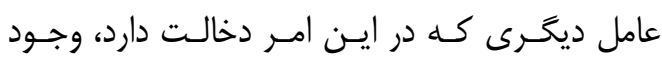

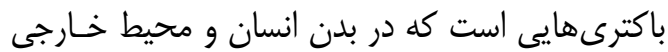

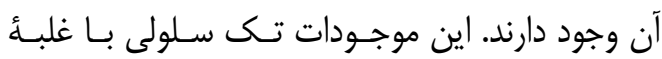

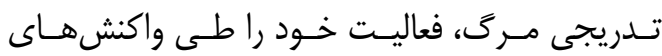
شيميايى و تجزئُ بافتهاى مرده شروع مى كنند. اين فين

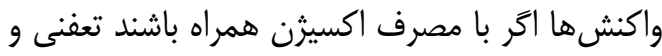

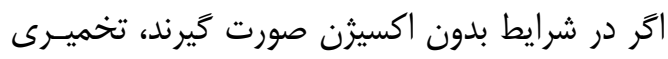
خوانده مى شوند. نوع باكترى و شرايط محيطى آن در تجزيئ جسد نقش مهمى دارد [21].

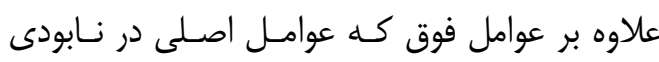
اجساد يا بقاياى انسانى هسـتند، مـوارد ديخـــى نيـز وجود دارند كه در اين فرايند به نوع ديخرى نقش خود الفائا

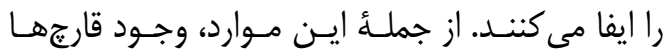

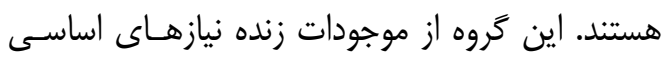

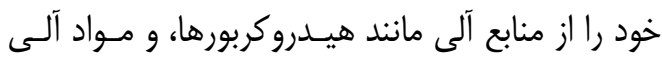
نيتروزن دار مانند يروتئين ها تأمين مى كنند. كاهى نيـز 
داخل ويترين و مجاور بودن بسـتهاى سـيليكازل در اطراف ساق پا مانع از افزايش رطوبت و وآسيب به به باى

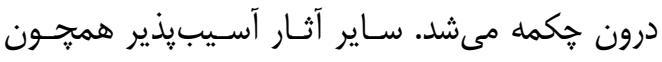

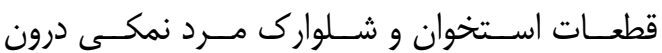
دسيكاتور همراه با سيليكازل قرار داده شدند.

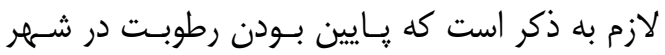

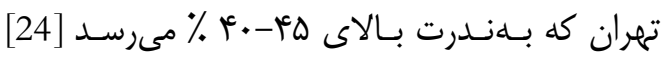

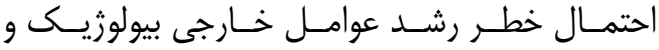

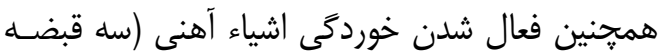
جاقو) در محيط داخل ويترين را كم مىكرد.

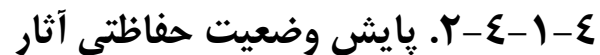

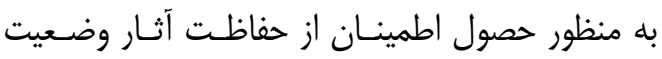

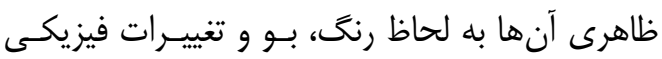

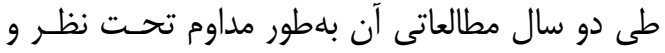

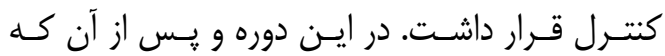

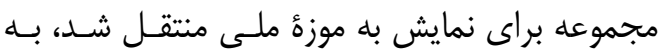

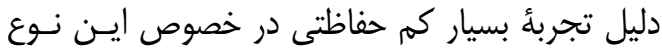

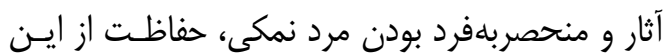

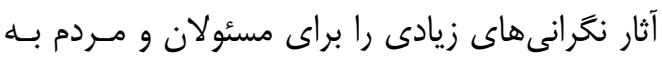

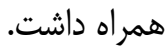

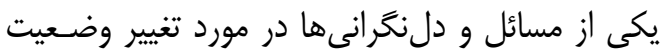

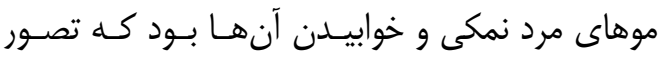
ريختكى يا خراب شدن بافتهاى سـر و صـورت و واز دست رفتن شادابى! روزهاى اول را ايجاد كـرده بـود.

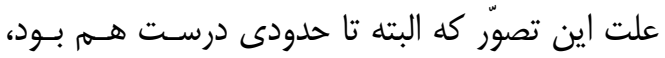

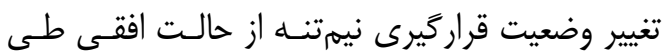

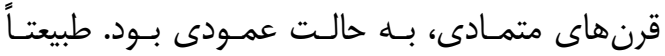

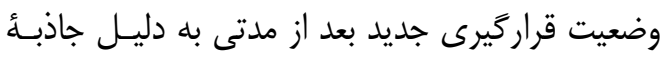
زمين موجب تغييـر جهـت و كشـيده شـدن بافتهـيا

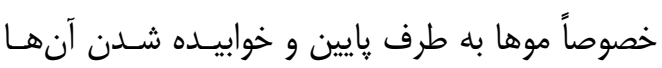

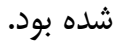
اما وقتى صحبت از خراب شدن موميـيـى كـه نــوعى فساد شيميايى و بيولوزيك است، مىشود اين فراينـد

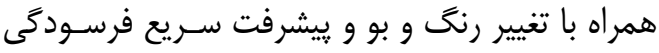

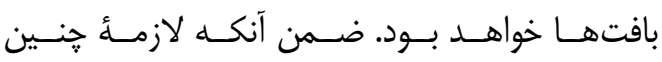

رنحَآميزى هماتكسـيلين و ائوزين (9H\&E) مـورد

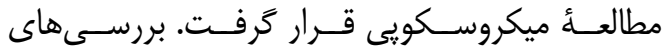

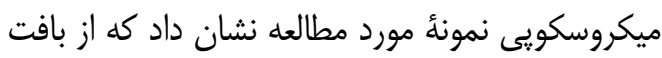

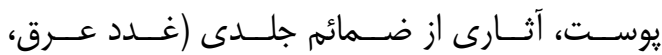
فوليكول هاى موى سر و غدد تربى) باقى مانده است. همجنين لايههاى شاخى كـراتين در ايبيدرم و سـائي

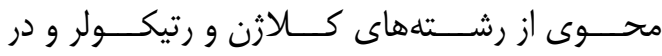
قسمتهاى عمقىتر، بقايـايى از رشـتهاي شكسـتأه عضلانى ديده شده است.

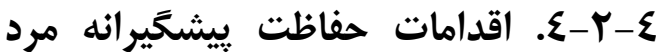 نمكى شماره}

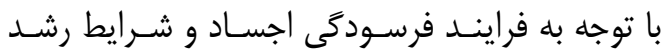

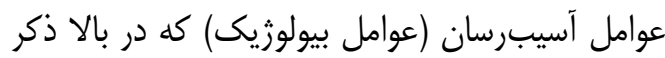

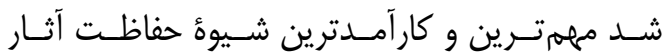

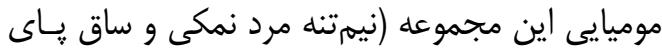

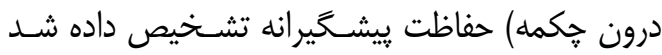

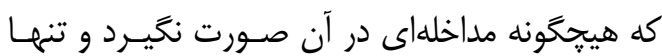

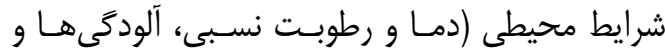

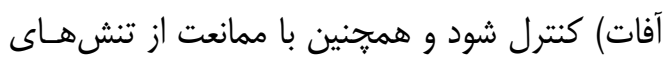
فيزيكى و مكانيكى از فرايند فرسودگى آثـار و آسـيب آنسي به آنها جلو تيرى شود.

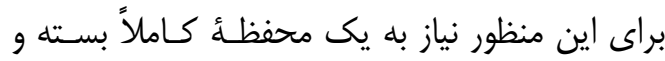

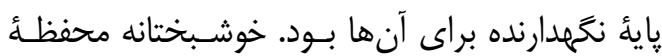

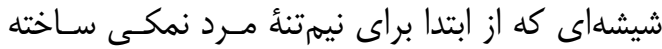

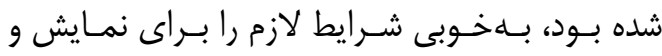

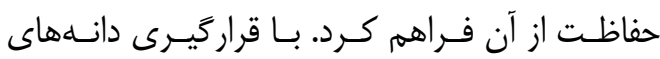
سيليكازل با شناساگر آبى در آن به عنوان بافر رطوبت إنى

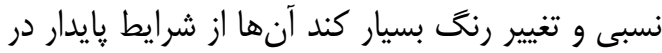

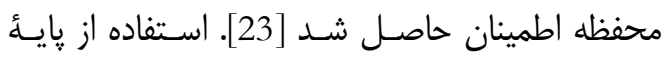

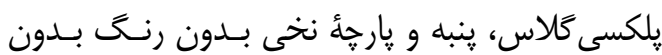

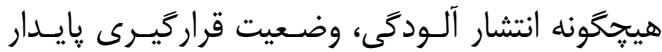
جمجمه را نيز امكانيذير كرد.

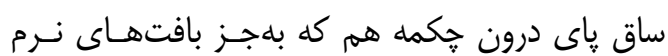

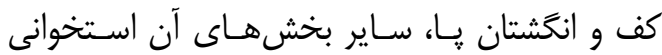

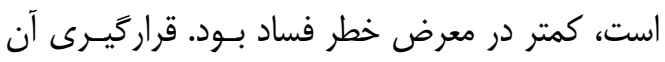


از باكترىهاى هوازى در نيمتنـه و جكمـه شناسـيى

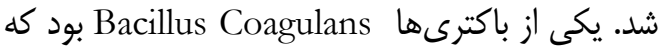

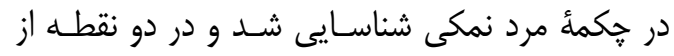

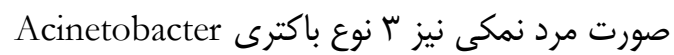
و Staphylococcus epidermidis spp Staphylococcus aureus

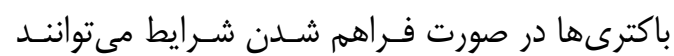

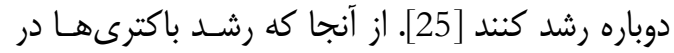

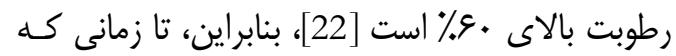

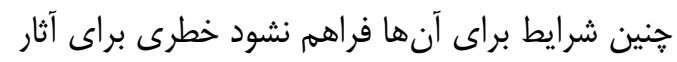
محسوب نمىشوند و نهايتاً بر اساس نتايج آزمايشـات

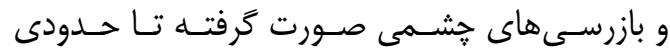
اطمينان از شرايط حفاظت و نكخهدارى اين آثار حاصل

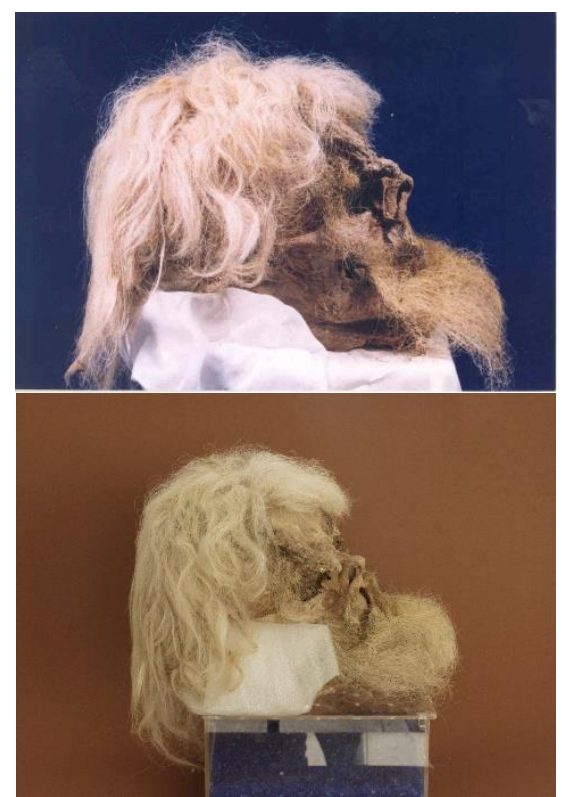

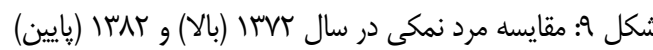

Fig. 9. Saltman in 1993 (up) and 2003 (down)

فيزيكى مشهودى در آن بهوجود نيامده بود. اكنون نيز

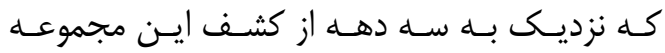

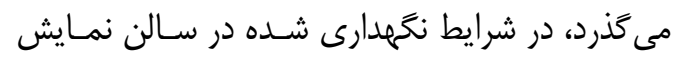

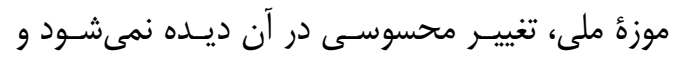

$$
\text { وضعيت ظاهرى آن مطلوب است. }
$$

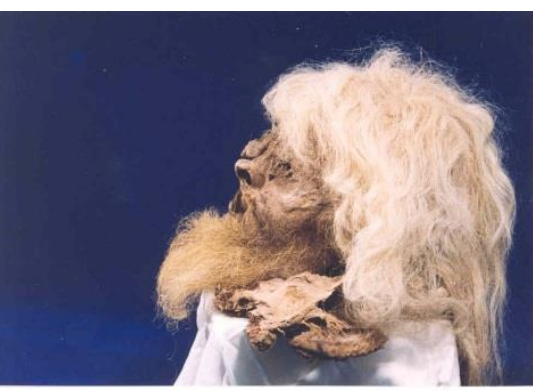

واكنشهايى در ابتدا رطوبت اضافى در محيط اسـت إنـ

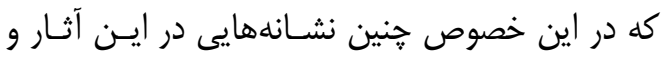

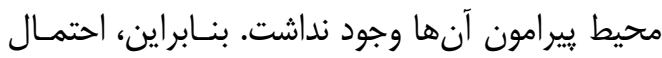

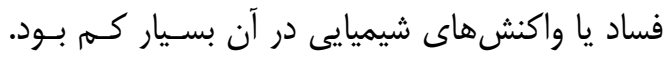
ضـمن انجـام קايشهــاى مرتسب دورهاى و ظـاهرى

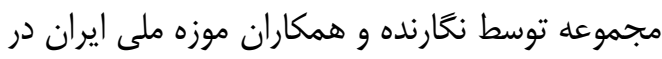

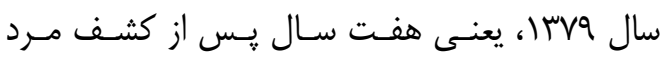

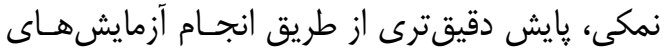

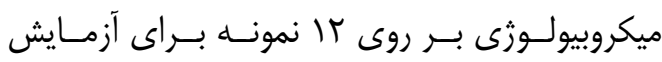

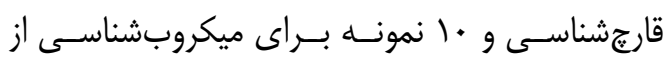

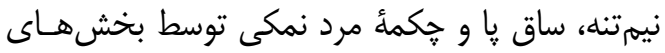

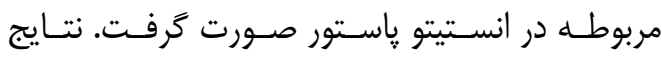

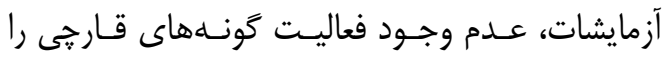

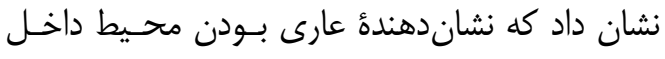

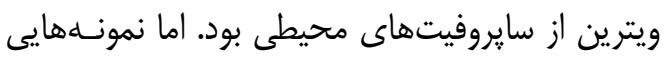

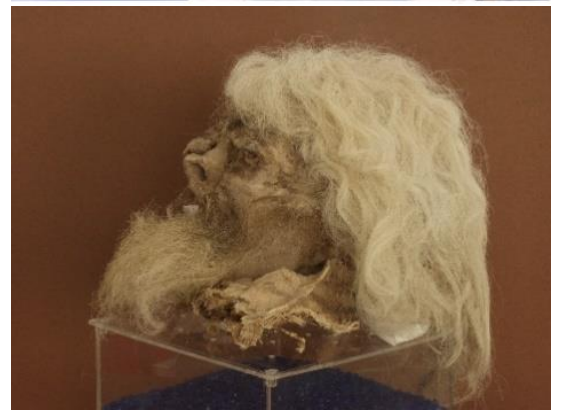

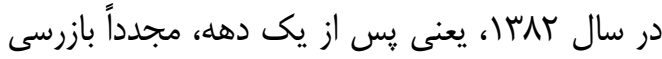

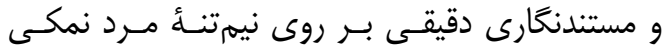

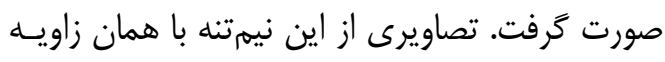

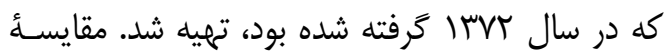

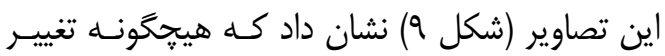


- - نصب بردههـاى كتـانى بـه منظـور كتتـرل نـور مستقيم خورشيد و ممانعت از جريان شديد هواى

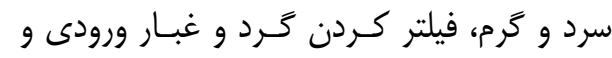
كمى به جذب رطوبت هوا، جلوى در و ينجرهـا.

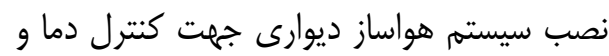

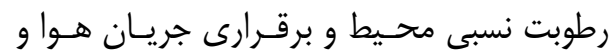

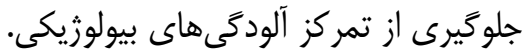

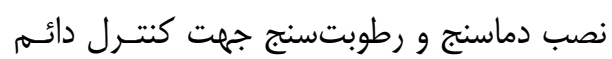

$$
\text { تغييرات آنها در محيط. }
$$

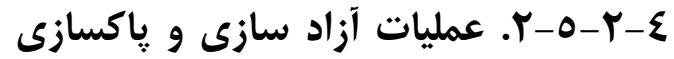

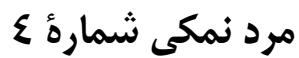

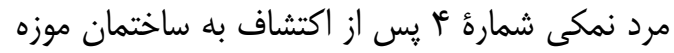

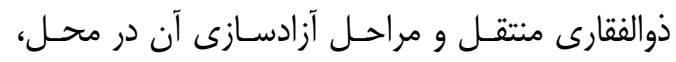

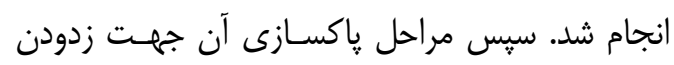

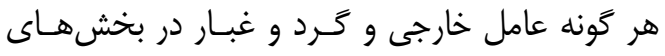

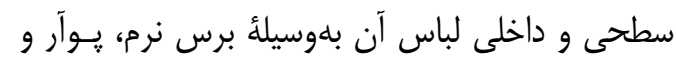
مكش ملايم جارو برقى با قدرت پإيين، تا حد امكـان

$$
\text { صورت گرفت (شكل • (1). }
$$

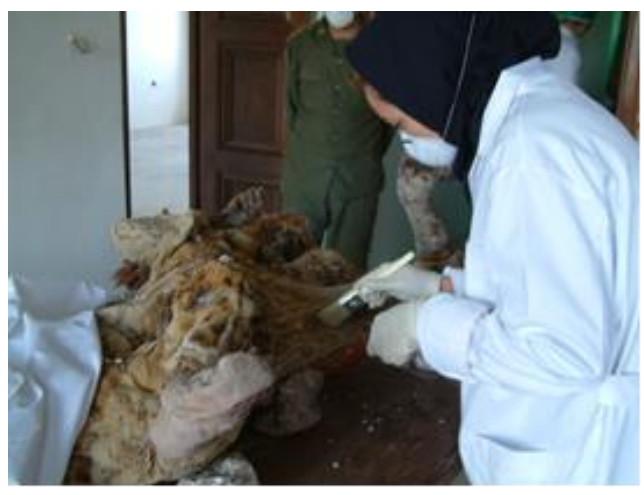

شكل • (: مراحل : باكسازى موميايى پِ از آزاد سازى كامل آن

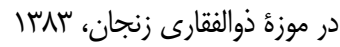

Fig. 10: Cleaning operation of Salt man no. 4 in the Zolfaghari museum in Zanjan, 2004

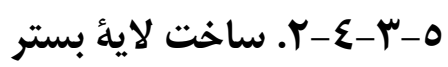

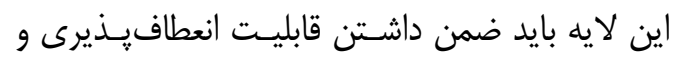
شكليذيرى متناسب با فرم مرد نمكى أل، از تـأثيرات

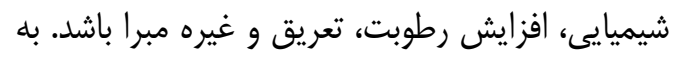

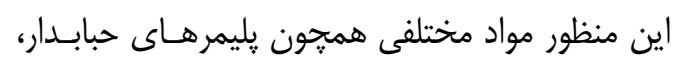

\section{ץ-0-ع. اقدامات حفاظتى مرد نمكى شماره}

\section{$\varepsilon$}

\section{ع-r-0- (. آمادهسازى فضاى نكَهدارى آثار}

محدوديت مكانى در ساختمان تاريخى رختشـوى إنانئ

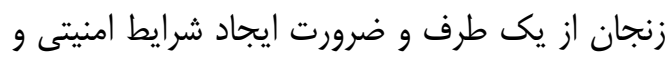

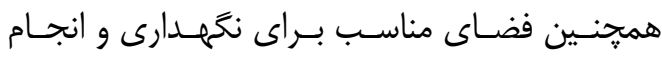
بررسىهاى لازم موجب شد كه سـاختمان ذوالفقـارى

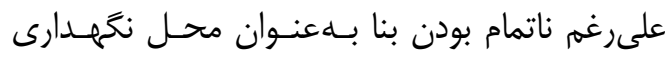
موقت آثار مكشوفه توسط مديريت وقت ميراث استان

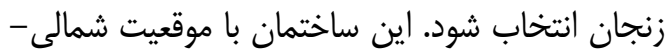

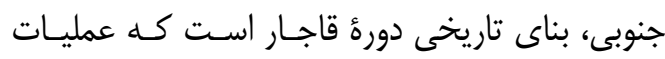

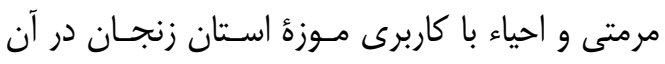

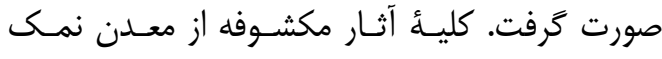

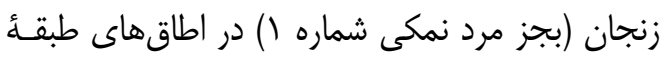

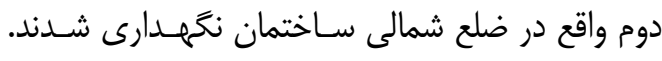

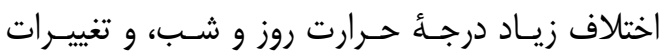

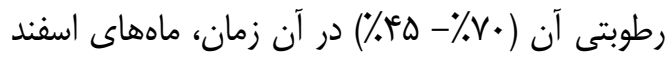

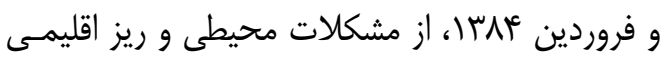

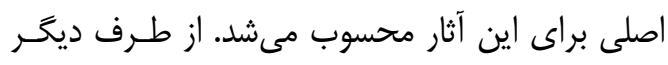

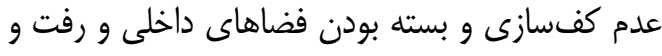

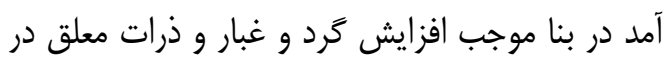

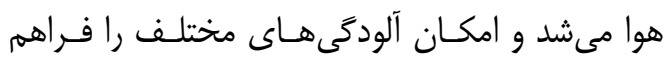
مى كرد. به اين منظور جند اقدام اساسى در اولويت قرار گرفت كه عبارت بودند از: ساماندهى اطاق و آثار موجود در آنس آن، ساخت لائُ بستر مناسب براى مرد نمكى شـماره

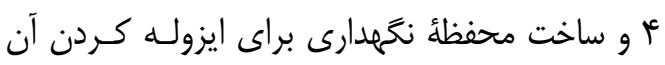

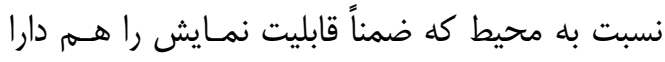

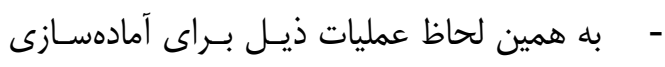

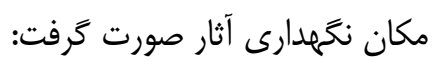

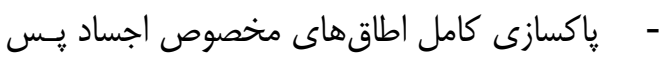

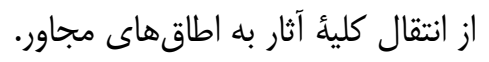

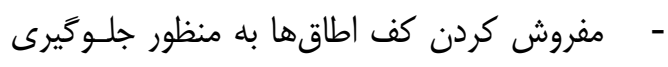
از عرد و غبار ناشى از رفت و و آمد. 
موميايى بر روى زمينة اسفنجى •ا سـانتى عـوارض

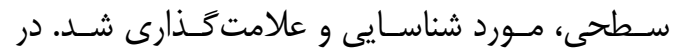
مرحلئ بعد، مقاطع مناسب فوم و اسفنج جهت ساسئ و عايورت

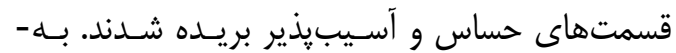
طورى كه تمامى گودى هاى اندامها مثل قوس كمـر و و

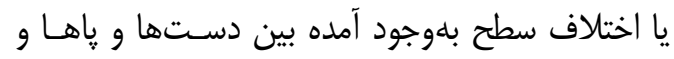
ديخر اجزاء ير شدند.
يونوليت گَرانول، فوم سرد، اسفنج و غيره مورد بررسى

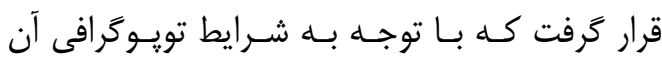

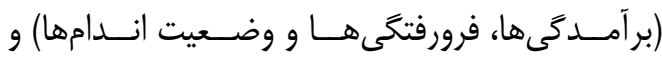
همجنين با توجه به امكانات موجود، بهترين انتخـاب

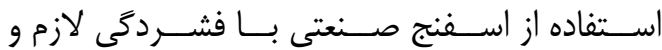

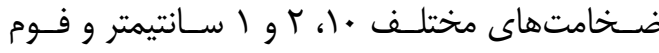
تشخيص داده شد. بنابراين با تهيئُ مواد لازم نسبت به اله ساخت لايه بستر اقدام شد. براى اين كار با قـرار دادن
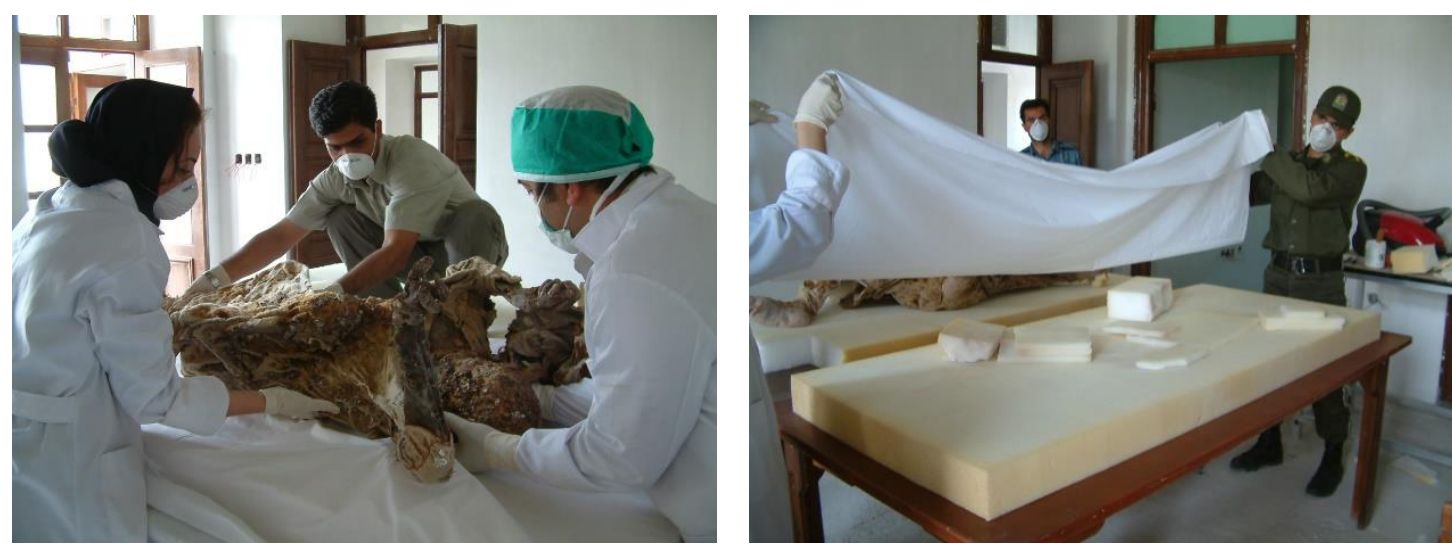

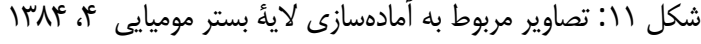

Fig. 11: Preparing the mummy's bed, 2005

ويثزى ها عبارت بودند از: ا - مستحكم و قابل جابـهـ-

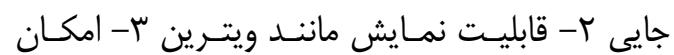
دسترسى آسان و بدون خطر به موميـايى أب- قابليـت كنترل شرايط ريز اقليمى داخل آن ه- سادخى كـافى مانى

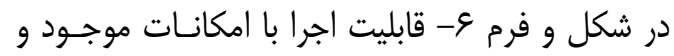
محلى.

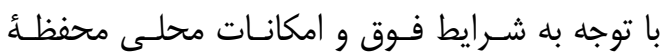

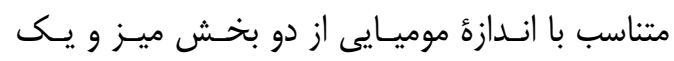

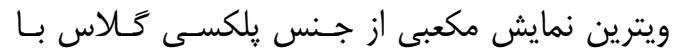
ضخامت ا سانتيمتر تشكيل مى شد. به منظور امكـان

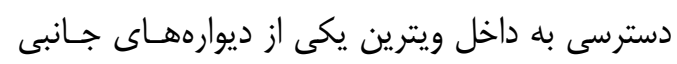

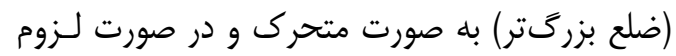
قابل باز شدن طراحى شد.

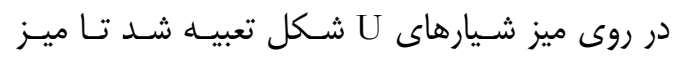
متحركى كه به عنـوان تكيـهكاه در زيـر لايـأه بسـتر

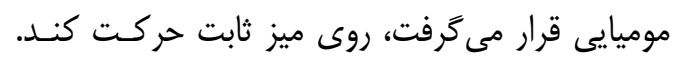

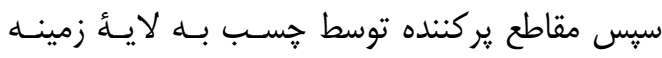

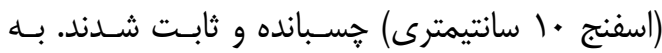
منظور عدم تماس مستقيم اسفنج با جسد و به حداقل

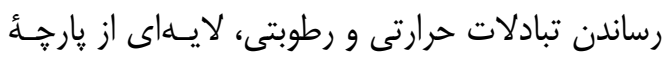

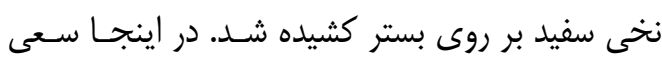

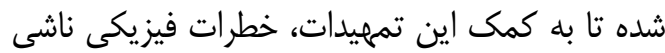

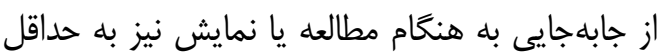

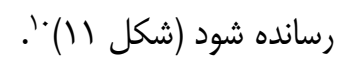

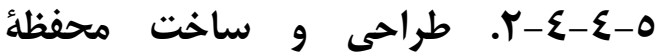

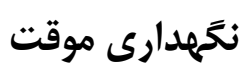

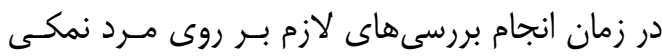

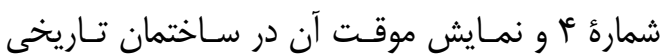
رختشوى خانه به مناسبت هفتلُ ميراث فرهنگى (هفته

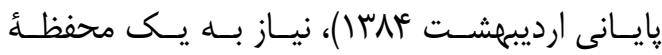

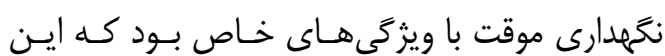


و بسته شدن كامل محفظه، رطوبت نسـبى داخـل آن تحت كنترل درآمد. لازم به ذكر است وجود سيليكاثل

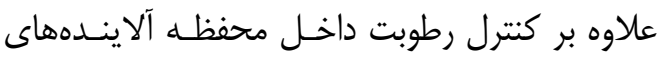

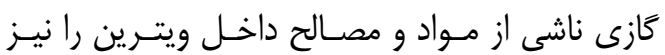

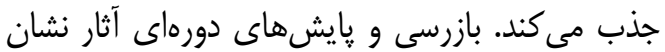

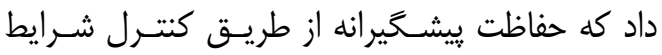

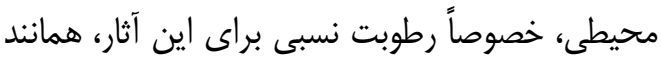

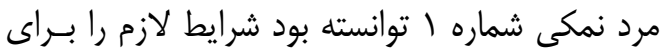
حفاظت آنها فراهم كند.

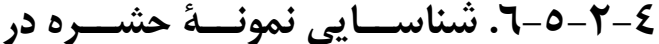

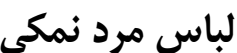

طى بازرسى و وايش مداوم مـرد نمكسى شـماره ثل، در

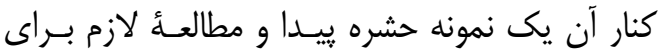

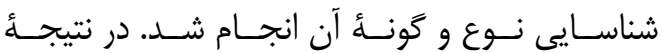
بررسى هاى لازم، اين حشره از نـوع درمـتس و كونــهـ

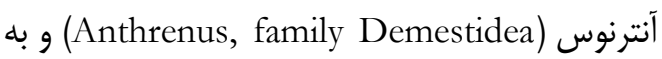
دليل فرم انتهايى بلدن آن حشـره، نـر تشـخيص داده

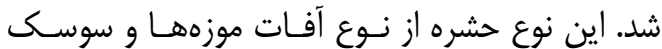

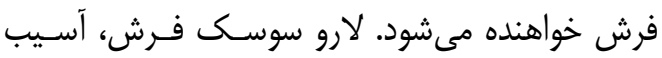

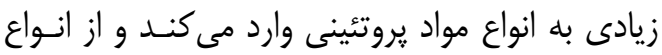

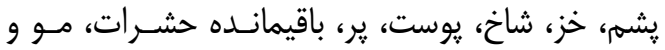

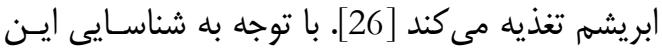

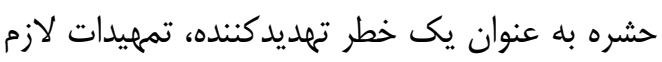

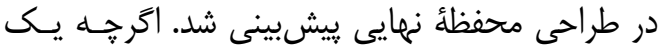
سئوال اساسى بدون پاسخ باقى مى ماند كه اين حشره متعلق به دوران كذشته بوده است يا حال؟؟ باسي

\section{ع-ץ-ט-V. ساخت ويترين نمايش مرد} نمكى شمارة ع در موزه ذوالفقارى

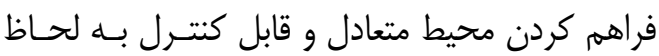

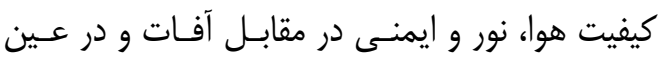
حال امكان معرفى و نمايش مطلوب اثر منحصر بـــــ

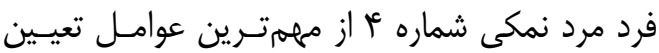

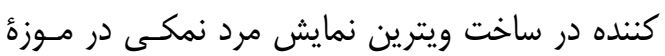
ذوالفقارى بود. وجود جنسيتهاى مختلف مواد اعم از
حركت اين تكيه كاه محدود و تنها در يـك مسـير بــهـ عقب و جلو و به منظور تسهيل كـردن ورود و خـروج

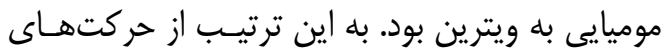

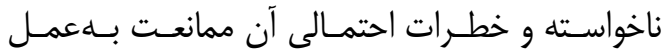
مى آمد. با قراركيرى ميز هم سـطح در كنـار محفظـهـ

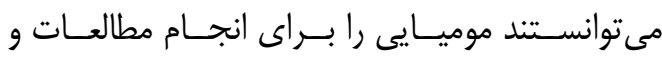
بررسىهاى لازم به راحتى با باز كردن ديـوارئ جـانبى إنى محفظه به روى آن منتقل كنند.

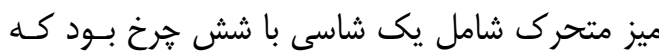
جرخها توسط ييج و مهره و واشرهاى فنـرى در زيـر

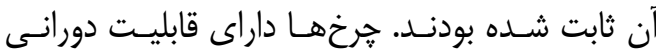

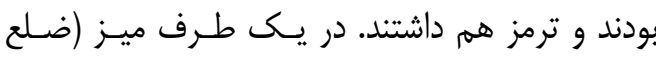

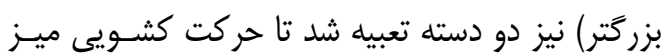

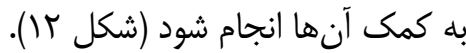

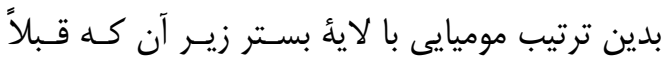

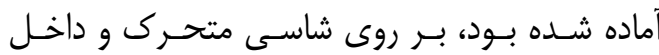

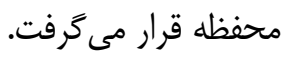

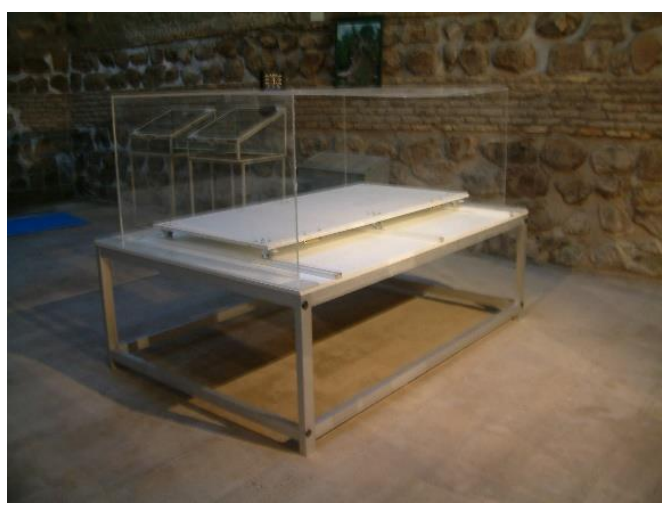

شكل r ا: فرم كلى محفظه نكُهدارى موقت مرد نمكى أ در

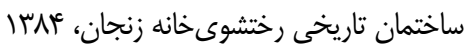

Fig. 12: the first display case of Saltman no.4 in Rakhtshooykhaneh Museum, Zanjan, 2005

\section{0-0-ع-r. كنترل شرايط ريز اقليمى}

طبق مطالعات و بررسىهاى انجام شده بـر روى مـرد نمكى شمارة ا، استفاده از سيليكازل به عنـوان مـادئ بافر در كنترل رطوبت محفظه نكَّهدارى اثار موميـايى مؤثر بوده است. بنابراين، با قرار دادن ظـروف حساوى درى سيليكازل در حدود نصف وزن اثر در اطراف موميـايى بنى 


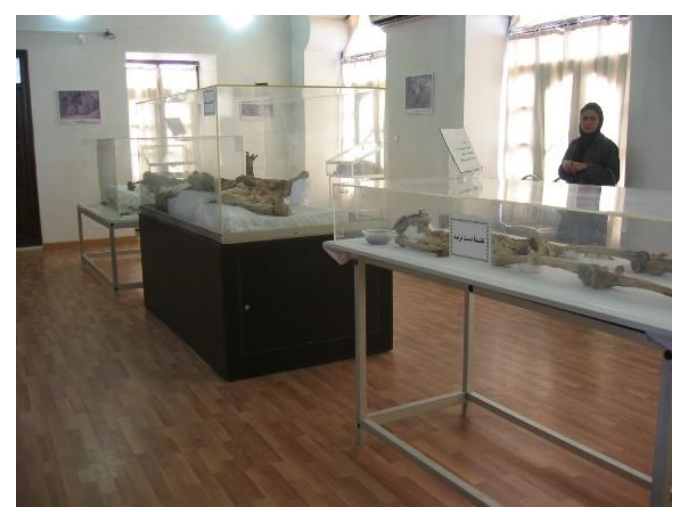

شكل سا: ويترين نمايش مرد نمكى شماره ع در موزه ذوالفقارى، سال هNץ"

Fig. 13: Display case of Saltman No. 4 in the Zolfaghary museum, 2006

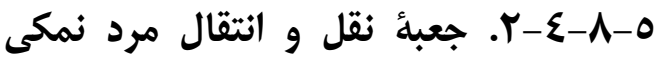

شماره

بــه منظـور مطالعـات آسيبشناسـى و تعيسين برخى مشخصات فردى مرد نمكى شماره أ، مثل تعيين سن

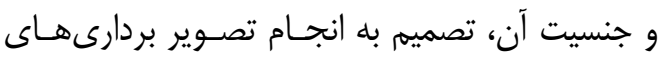

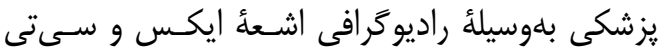

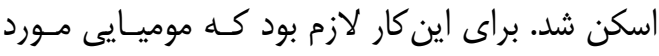

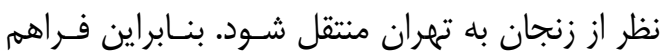

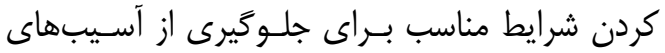

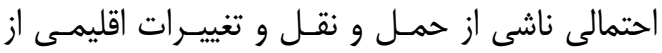

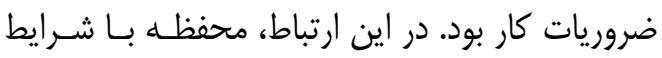
زير طراحى و سبس عمليات اجرايى ساخت آن (شكل (1) با شرايط اصلى ذيل انجام شد: 1- استحكام و دارا بودن حداقل وزن لازيط إم برام إنى حمل توسط انسان با استفاده از يروفايل آلومينيه و فيبر.

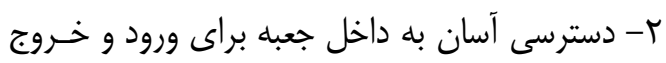
موميايى با دو در بازشوى جانبى و فوقانى. ب- سادگى حمل جعبه با نصب دستخيرؤ مناسب.

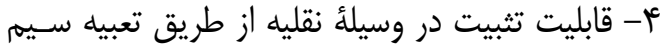
بكسل هايى كه به وسيلة قلاب و فنرهاى مخصـوص

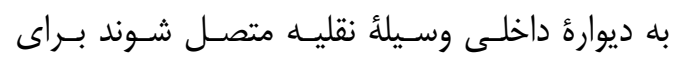
جلوگيرى از لرزش و تكان هاى ناگمانى.

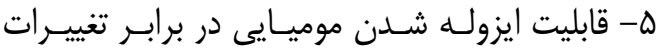
شرايط محيطى با بسته شدن دقيق درزهاى محفظه و

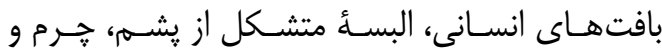

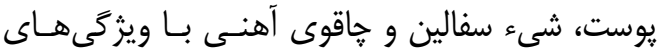

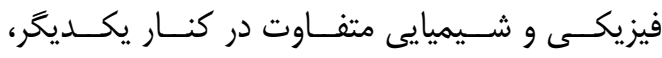

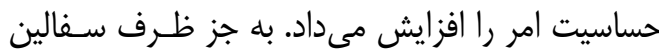
كه در برابر عوامل محيطى، مقاومت بيشترى از خـود

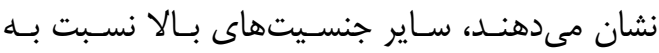
آلايندهها و افت و خيزهــاى دمـا و رطوبـت و و آفـات

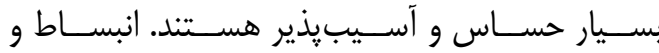

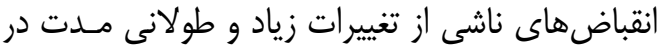

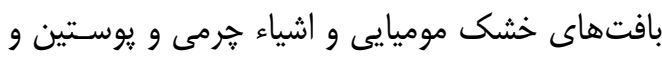

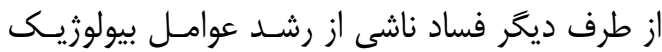

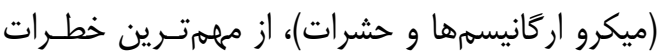

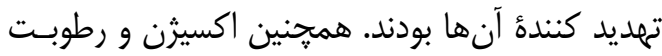

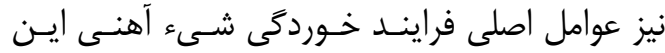

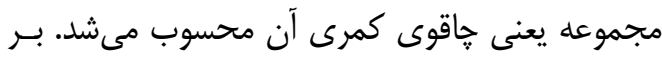

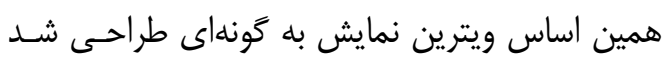
كه ضمن سادگى و در نظر حَرفتن كيفيـت نمـايش، محفظهاى براى قرارگيرى دانههاى سيليكازل در زيــر

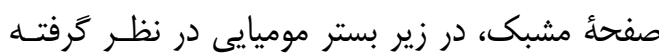

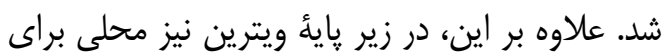

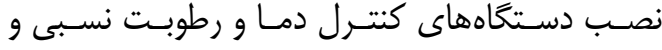

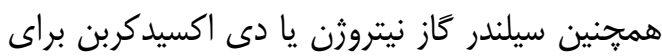

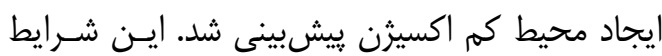

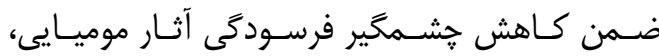

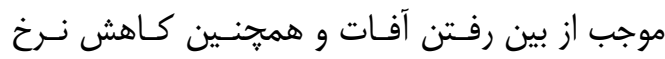

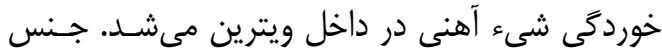

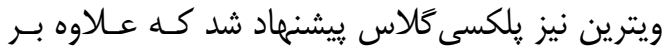

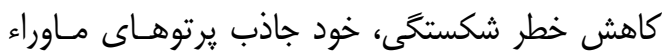

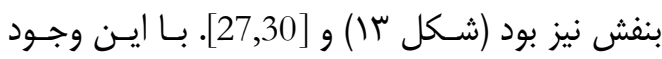
اكنون استفاده از شيشه به دليل ايمن بودن شـيميايى

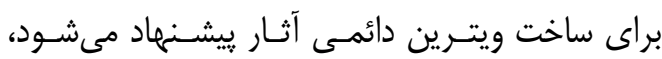

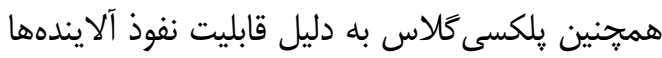

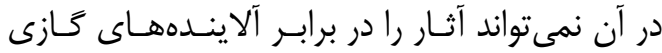
بيرونى محفوظ نكمهارد [30]. 
نبودند و البته اثبات اين ادعا نيازمند اطلاعات دقيقتر

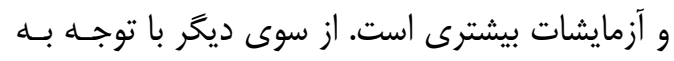

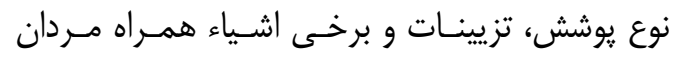

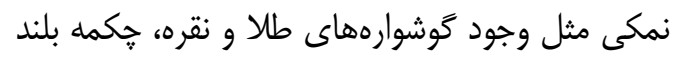

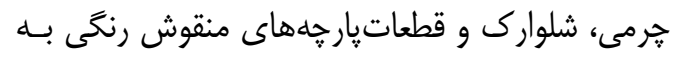

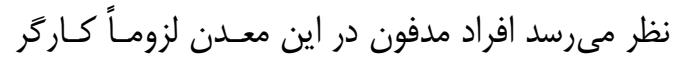

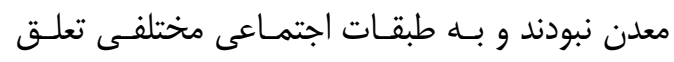

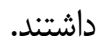
بررسى فرايند فرسودگى مردان نمكى كـه عـاولاوه بــر

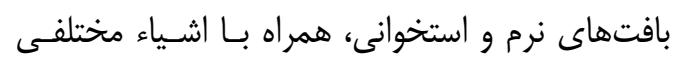

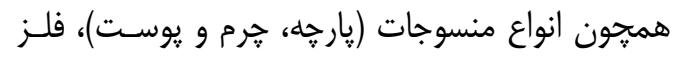

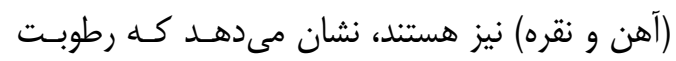
نسبى يكى مهمترين متغيرهاى محيطى مؤثر در ايـن

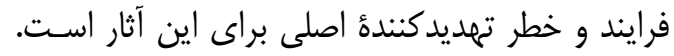

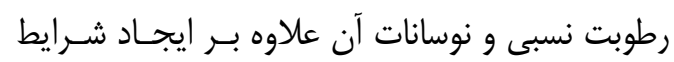

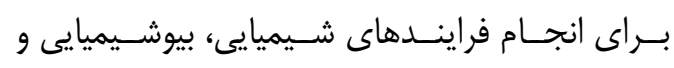

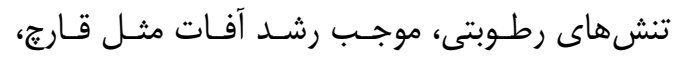

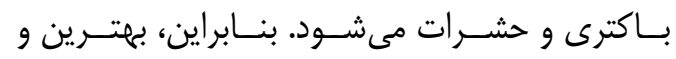

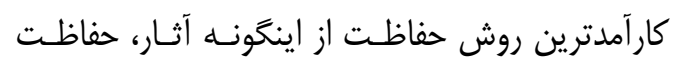

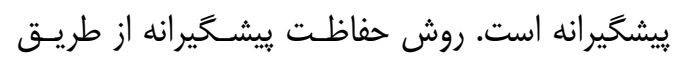

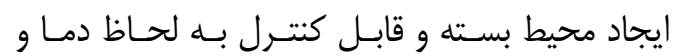

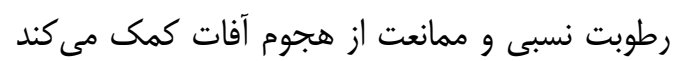

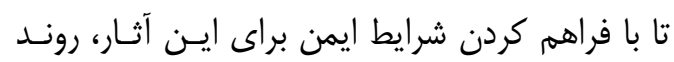

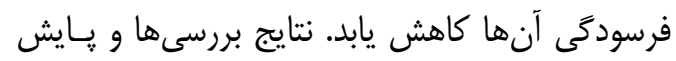

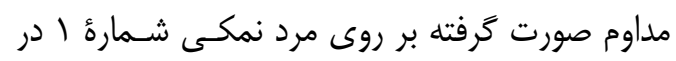

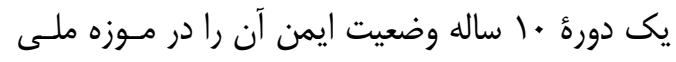
ايران تحت شيوه حفاظت يِيشخيرانه به اثبات رسـاند.

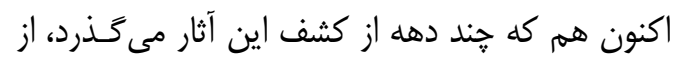

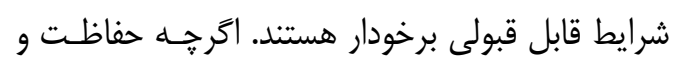

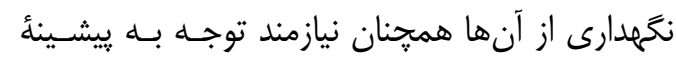

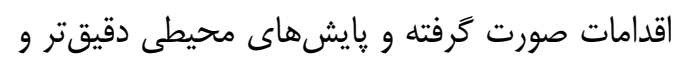
مداومى براى بهبود وضعيت و تحت كنترل بودن اين

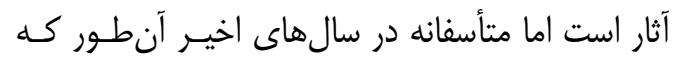

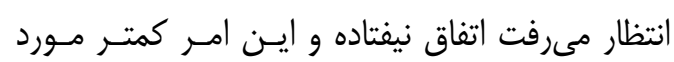
توجه قرار گرفته است.
يوشش كامل آن با مواد جاذب مانتـــ يارجـــ نخـى و يركردن فضاى داخل محفظه با كاغذ غيراسيدى.

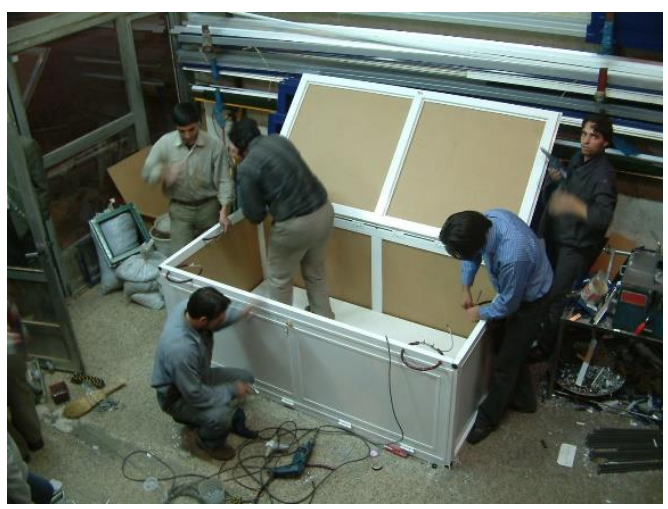

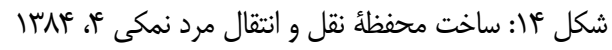
Fig. 14: making transportation case of Saltman no. 4, 2006

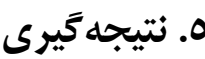

در مجمـوع، مطالعـات ميانرشــتهاى بـــر روى آثـار

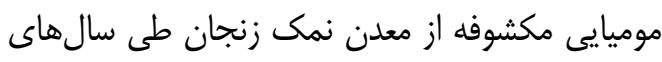

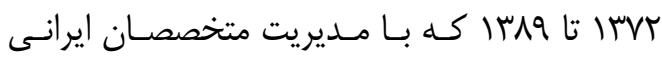

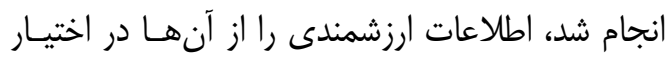

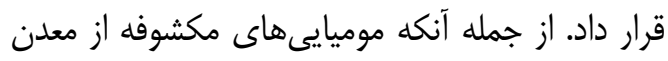

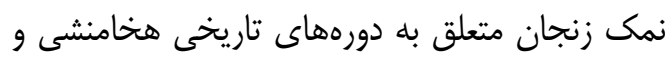
يارتى -ساسانى هستند. وضعيت قراركيـرى اجسـاد در دران

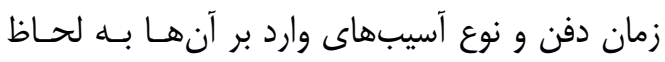

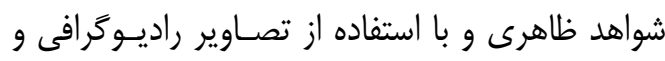

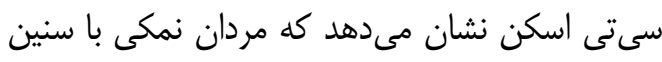

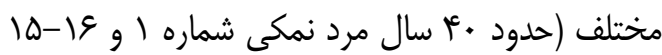

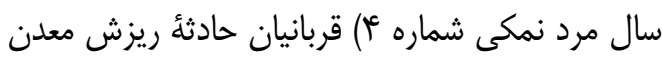
در دورههاى تاريخى فوق و وارد شدن ضربات شـديد

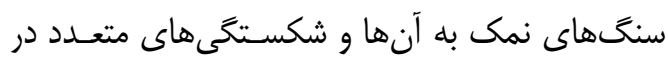

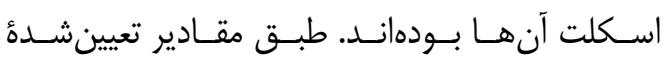

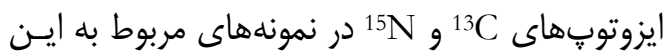

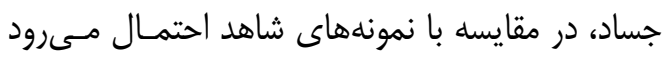
رزيم غذايى آنها نزديك به رزيم دريسايى باشـد. بــر

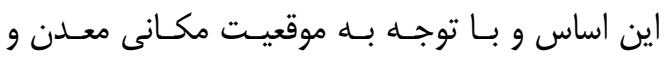

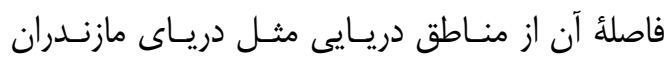

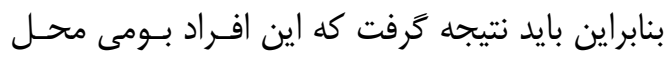




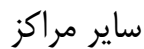

- جناب آقاى دكتر جلال جلال شكوهى، متخصص

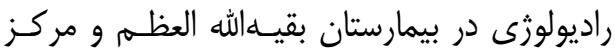

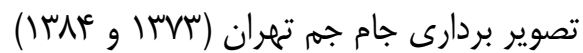
جناب آقايان دكتر: احمدرضا بهرهمند و محمدرضا يورشفيع، بخش ميكروبشناسـى انسـتيتو باسـتور

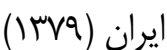

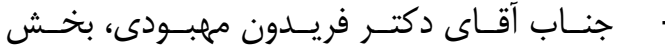
بيوتكنولوزى انستيتو پاستور ايران (ع أبسا)

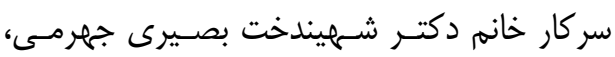
بخش قارجشناسى انستيتو پاستور ايران (IFV9)

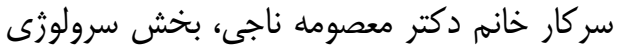

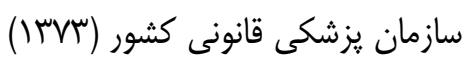
جناب آقاى دكتر عباس شكور، بخش بانى بافتشناسى سازمان يزشكى قانونى كشور (ساستا)

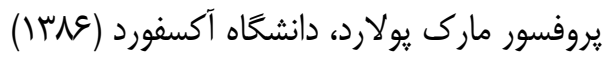
جنــاب آقـاى دكتــر مرتضـى فتــاحى، دانشــاه

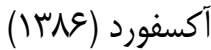

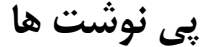

1. Accelerated Mass Spectroscopy

2. Before present

3. Polymerase chain reaction

يك تكنيك رايج آزمايشگاهى است كه در تكثير PCR

قطعه مشخصى از DNA به كار مىرود.

4. Restriction fragment length polymorphism (pronounced "rif lips")

در زيستشناسى مولكولى، يلى مورفيسم قطعـات طـولى لى

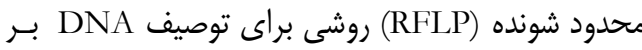

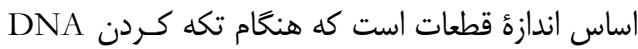

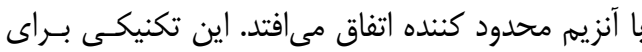
اثبات شباهت دو مولكول DNA است.

5. Human Leukocyte antigens

HLA به ماركرهاى (آنتىثن) اختصاصى در سطح تمامى

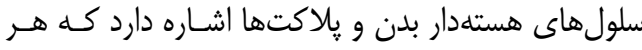

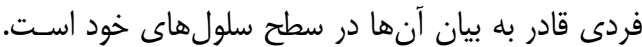

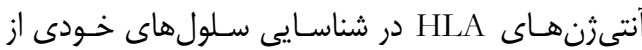
غيرخودى اهميت دارد.
سياسگز ارى

شايسته و بايسته است از همأ مراكز و همكارانى كـهـ

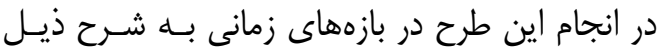

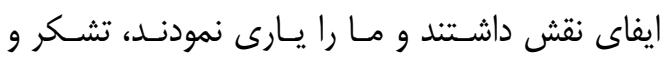

$$
\text { قدردانى ويزه شود: }
$$

يزوهشكده حفاظت و مرمت آثار تاريخى -فرهنكى

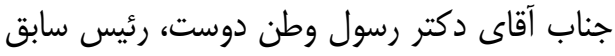

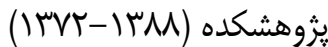

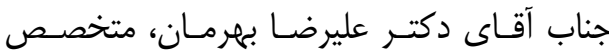

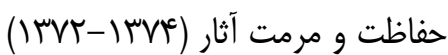

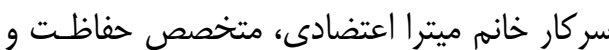

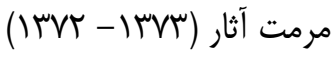

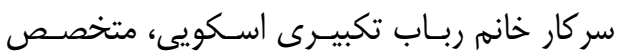

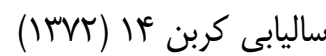
سر كار خانم فرشته رحيمسى، متخصـص شـيمى و

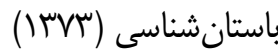

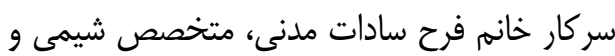

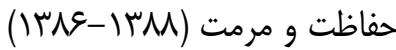
جناب آقاى شماب سـيفى، كارشـناس حفاظـت و

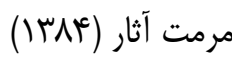

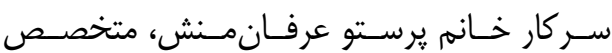

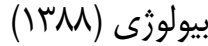

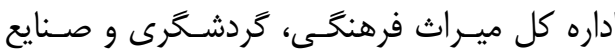
دستى استان زنجان جناب آقاى رحمتى مدير كل وقت (عیىسا-سرسا)

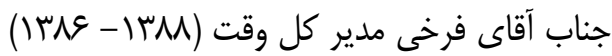
جناب آقاى دكتر هوشنَ ثبوتى سريرست هيئست حفارى معدن نمك در سال بrr جناب آقاى امير الرهى سريرسـت هيئـت حفــارى

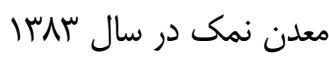

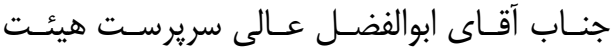

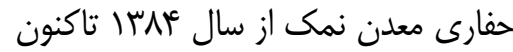
موزه ملى ايران جناب آقاى محمدرضا كارگر رييس وقت سر كار خانم دكتر مهناز عبداله خان گرجى، بخش حفاظت و مرمت موزه ملى ايران (IMM (IMV- 


$$
\begin{aligned}
& \text { مولكولهاى محلول مثل بروتئينها را نيز مىتـوان بــه }
\end{aligned}
$$

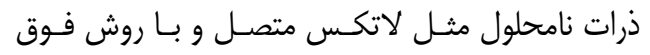

$$
\begin{aligned}
& \text { بررسى كرد (https://iums.ac.ir). }
\end{aligned}
$$

9.Hematoxylin and Eosin

•l. سال و9 إ و يس از ها سال بستر مرد نمكى شـماره

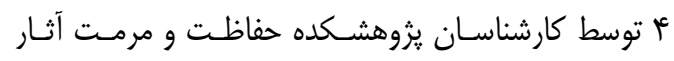

تعويض شد.

\section{References}

[1] Sobouti, H., Preliminary report of the body discovered from the salt mine of Hamzehloo village, Zanjan Cultural Heritage Organization, 1994. [in Persian]

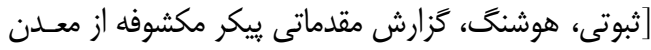

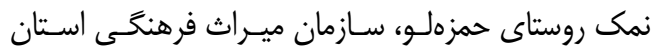

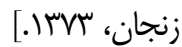

[2] Ali, A.; Stolner, T.; Firoozmandi, B., Analysis of the results of archaeological excavations in Chehrabad salt mine, Archaeological Studies, 2019, Volume 11, Number 2, pp. 210-219. [in Persian]

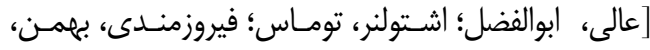

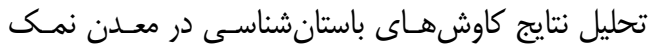

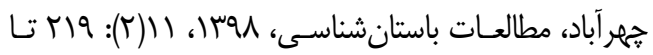

$[.4)$.

[3] Aali,A., Abar, A., Boenke, N., Pollard , M., Rühli , F., Stöllner , T., Ancient salt mining and salt men: the interdisciplinary Chehrabad Douzlakh project in northwestern Iran, Antiquity, vol. 086, 2012.

[4] Sobouti, H., Preliminary report of Zanjan Saltman, Memoirs of Susa Archaeological Conference, Volume 1, Cultural Heritage Organization (Research Institute), 1997: pp. 63-81. [in Persian]

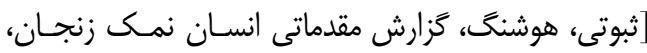

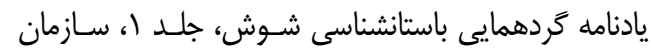

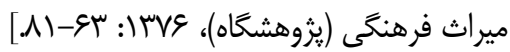

[5] Elahi, A., Investigation of Archaeological Potentials and Priorities of Chehrabad Salt Mine, Second Salt Men Seminar, Archaeological Research Institute and Zanjan Cultural Heritage, Handicrafts and
و. لازم به توضيح است بررسى سى تى اسكن مرد نمكى

شماره ع مجدداً در سال •وسا توسط تئم آلمـانى تكـرار

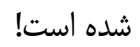

7. Inductivly coupled plasma

8. Agglutination

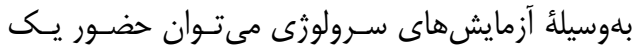

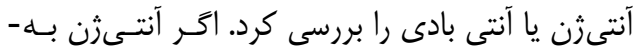

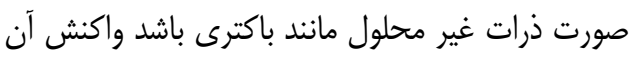

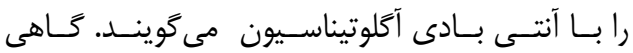

Tourism, Organization, Zanjan November 2007. [in Persian]

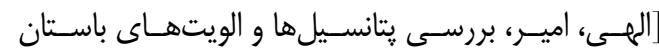

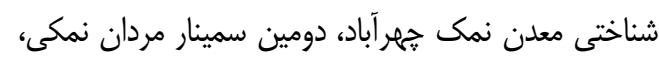

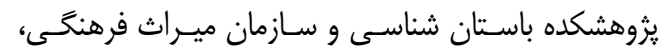

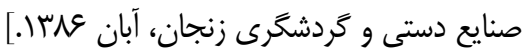

[6] Ali, A., Chehrabad Salt Mine: New Archaeological Research Report, 20042005, 2006. [in Persian]

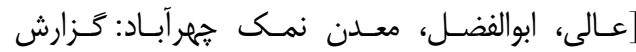

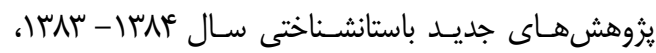

$[.1 \mathrm{r}$ No

[7] Hadian Dehkordi, M., Application of scientific investigation in conservation and restoration of historical buildings (building materials), University of Tehran Press, 2007: pp. 204-206. [in Persian]

[هاديان دهكردى، منيزه، كاربرى مطالعات علمى بـر روى .

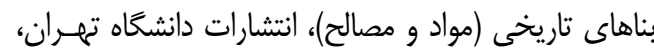

[.IrNe

[8] Linick, T.W.; Damon, P.E.; Donahue, D.J.; Jull, A.J.T., Accelerator mass spectrometry: The new revolution in radiocarbon dating, Quaternary International, 1989, Volume 1, Pages 1-6.

[9] Orlando, L.; Allaby, R.; Skoglund, P.; Der Sarkissian, C.; Stockhammer, Ph. W.; ÁvilaArcos, M. C.; Fu, Q.; Krause, Johannes; W., Eske; Stone, A. C. and Warinner, Ch., Ancient DNA analysis, Nature Reviews Methods Primers, volume 1, 2021.

[10] Lawlor, D. A., Hauswirth, C. D. Dickel, P., William W. \& P., Ancient HLA genes from 7,500-year-old archaeological remains, Nature, 1991, volume 349, pages785-788. 
[11] Rankin DR, Narveson SD, Birkby WH, Lai J., Restriction fragment length polymorphism (RFLP) analysis on DNA from human compact bone, J Forensic Sci.; 1996, 41(1) :40-6.

[12] Hummel, S., Schmidt, D., Kahle, M. et al, AB0 blood group genotyping of ancient DNA by PCR-RFLP. Int J Legal Med 116, 2002: 327-333.

[13] Vatandoust A. R.; Hadian Dehkordi, M., "Saltman" a New Archaeological Discovery: Scientific Investigation and Conservation, Journal of Biological Research, n.I-vol. LXXX-Rubbettino-Soveria Mannelli, 2005: 236-242.

[14] Hadian Dehkordi, M.; Jalal Shokouhi, J.; Aali, A.; Pollard, M., Pathology, SEX and AGE Estimation to Decode the 4th Salt Mummy, the Saltmine in Zanjan, Iran, The International Journal of Humanities, 2021

[15] Hunter, D., The Diseases of Occupations, English Universities Press, London, 1955.

[16] Pollard, A. M.; Brothwell, D. R.; Aali, A.; Fazelli, H.; Vatandoust, R.; Hadian Dehkordi, M.; Wilson, A.S.; Jones, A.; Shokouhi, J.J.; Buckley, S. and Holden, T., Below the Salt: A Preliminary Study of the Dating and Biology of Five Salt-Preserved Bodies from Zanjan Province, Iran, Iran, Vol. 46, 2008: pp. 135-150.

[17] Katz, S. A.; Chatt, A., Hair Analysis: Applications in the Biomedical and Environmental Sciences, VCH Publishers, 1998.

[18] Pollard, A Mark; Heron,Carl, (2008). The Chemistry of Human Bone: Diet, Nutrition, Status and Mobility, Archaeological Chemistry: Edition 2, pp. 346-382.

[19] Knight, B., Forensic Pathology, 2nd Ed. Arnold, London, 1996: pp. 51-94.

[20] Pinheiro, J., Decay Process of a Cadaver from Forensic Anthropology and Medicine:
Complementary Sciences from Recovery to Cause of Death Edited by: A. Schmitt, E. Cunha, and J. Pinheiro (C) Humana Press Inc., Totowa, NJ, (n.d).

[21] Tarnowski, W., Mumien, Published by Hamburg, Tessloff, 1988.

[22] Thomson, G., The Museum Environment, BUTTERWORTH-HEINEMANN, 1998.

[23] Zhang, G.; Zhang, Y.F.; Fang, L. Theoretical study of simultaneous water and vocs adsorption and desorption in a silica gel rotor. Indoor Air 2008, 18, 37-43.

[24] http://www.weatheronline.de

[25] Jawetz, E., Melnick, J. L., \& Adelberg, E.A., Jawetz, Melnick, \& Adelberg's Medical Microbiology (28 edition), 2019

[26] Pinniger D., Saving our heritage - pest management in museums and historic houses, Research Information Ltd, 2010.

[27] Iskander, N. Y. Controlled-Environment Cases for the Royal Mummy Collection, Oxygen- free museum cases, The Getty Conservation institute, USA, 1998.

[28] Gian Luigi, N.; Marco, N.; Alessandro, N. Preservation and Conservation of Mummies and Sarcophagi, e- Conservation, 2008.

[29] Maekawa, Sh. Conservation of the Royal Mummy Collection at the Egyptian Museum, Oxygen- free museum cases, The Getty Conservation institute, USA, 1998.

[30] Hansen, E. F., Protection of Objects from Environmental Deterioration by Reducing Their Exposure to Oxygen, Oxygen- free museum cases, The Getty Conservation institute, USA, 1998.

[31] Tetreault, J., Airborn pollutants in museums, galleris, and Archives: Risk assessment, control strategies and preservation management, Canadian Conservation Institute, 2003. 